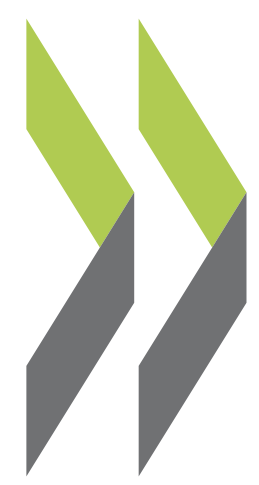

OECD Economics Department Working Papers No. 636

\title{
A Taxonomy of Instruments to Reduce Greenhouse Gas Emissions and their Interactions
}

\section{Romain Duval}


Organisation de Coopération et de Développement Économiques

Organisation for Economic Co-operation and Development

ECONOMICS DEPARTMENT

English - Or. English

\begin{abstract}
A TAXONOMY OF INSTRUMENTS TO REDUCE GREENHOUSE GAS EMISSIONS AND THEIR INTERACTIONS
\end{abstract}

ECONOMICS DEPARTMENT WORKING PAPER No. 636

by Romain Duval

All OECD Economics Department Working Papers are available on the OECD internet website at www.oecd.org/eco/working_papers

JT03250687

Document complet disponible sur OLIS dans son format d'origine

Complete document available on OLIS in its original format 


\begin{abstract}
RESUMÉ
A taxonomy of instruments to reduce greenhouse gas emissions and their interactions

This paper reviews alternative (national and international) climate change mitigation policy instruments and interactions across them. Carbon taxes, cap-and-trade schemes, standards and technology-support policies (R\&D and clean technology deployment) in particular are assessed according to three broad costeffectiveness criteria, their: i) static efficiency, defined to cover not just whether the instrument is costeffective per se but also whether it provides sufficient political incentives for wide adoption; ii) dynamic efficiency, which implies an efficient level of innovation and diffusion of clean technologies in order to lower future abatement costs; iii) ability to cope effectively with climate and economic uncertainties. Multiple market failures and political economy obstacles need to be addressed in order to meet these criteria. In this regard, carbon taxes or cap-and-trade schemes appear to perform better than alternatives. However, their cost-effectivenes can be enhanced through targeted use of other instruments. There is therefore room for climate policy packages.
\end{abstract}

JEL classification: $\mathrm{H} 23$; Q54

Key words: climate change; global warming; greenhouse gas; mitigation; international climate policy

\title{
$++++$ \\ Une taxonomie des instruments de réduction des émissions de gaz à effet de serre et de leurs interactions
}

Cet article passe en revue les différents instruments de politique économique (nationaux et internationaux) envisageables dans la lutte contre le changement climatique, ainsi que leurs interactions. Taxes carbone, marchés de permis négociables, standards et politiques de soutien au progrès technique (R\&D et déploiement de technologies propres) en particulier sont évalués au regard de trois critères d'efficacité coût, à savoir: i) l'efficience statique, qui recouvre non seulement l'efficacité coût intrinsèque de l'instrument, mais aussi les incitations politiques à son adoption à grande échelle; ii) l'efficience dynamique, impliquant un niveau efficient d'innovation et de diffusion des technologies propres permettant de réduire les coûts futurs de réduction des émissions; iii) la capacité à s'adapter aux incertitudes climatiques et économiques. De multiples échecs de marché et obstacles relevant de l'économie politique doivent être surmontés pour vérifier ces critères. De ce point de vue, il apparaît que les taxes carbone et les marchés de permis négociables sont plus performants que les alternatives. Néanmoins, leur efficacité coût peut être améliorée par un usage ciblé des autres instruments. Il y a donc matière à la mise en place d'un éventail de politiques.

Classification JEL : H23; Q54

Mots clés: changement climatique; réchauffement climatique; gaz à effet de serre; réduction des émissions; politique climatique internationale

Copyright OECD, 2008. All rights reserved.

Application for permission to reproduce or translate all, or part of, this material should be made to: Head of Publications Service, OECD, 2 rue André-Pascal, 75775 PARIS CEDEX 16, France. 
TABLE OF CONTENTS

\section{A TAXONOMY OF INSTRUMENTS TO REDUCE GREENHOUSE GAS EMISSIONS AND

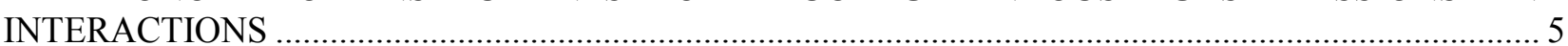

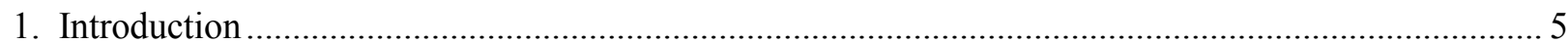

1.1 A simple framework for thinking about climate mitigation policy instruments ....................... 6

2. Assessing the cost effectiveness of available climate mitigation policy instruments ....................... 9

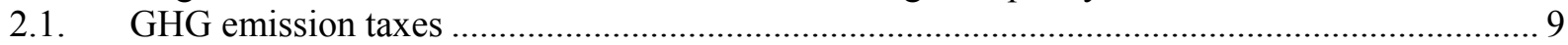

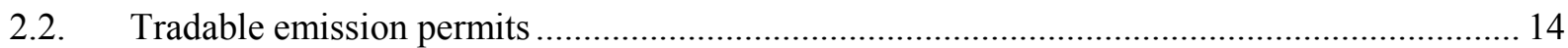

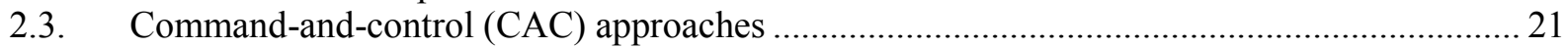

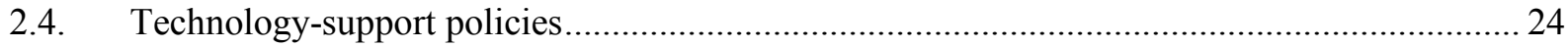

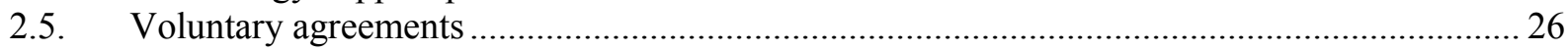

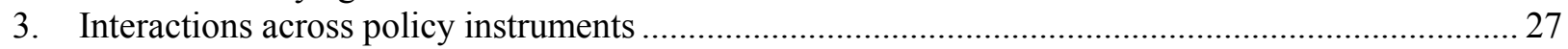

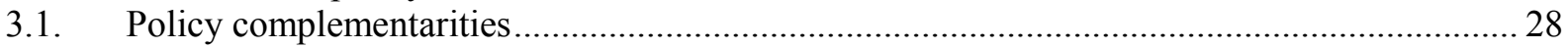

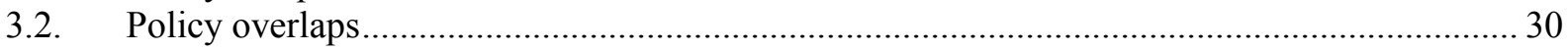

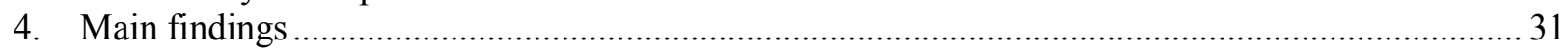

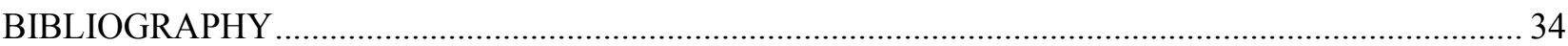

\section{Boxes}

Box 1. A brief overview of international sectoral approaches to address GHG mitigation ..................... 16 Box 2. Do R\&D and technology adoption incentives under GHG emission taxes and simple cap-andtrade schemes differ? 


\section{ECO/WKP(2008)44}


ECO/WKP(2008)44

\title{
A TAXONOMY OF INSTRUMENTS TO REDUCE GREENHOUSE GAS EMISSIONS AND INTERACTIONS
}

\author{
By Romain Duval ${ }^{1}$
}

\section{Introduction}

1. The political appeal of any post-2012 international climate policy framework will ultimately hinge, to a large extent, on its overall cost-effectiveness and the way costs and benefits are spread across emitters. In turn, cost effectiveness both across and within countries will be determined by the choice and design of the policy instruments that will be selected to reach any particular climate objective. It is, therefore, of key importance to policymakers to be fully aware of the pros and cons of each available instrument, as well as whether and how these can be integrated into a coherent framework. Moreover, in order to address climate change at least cost, instruments will have to be applied as widely as possible across emission sources. This means that policy design will have to build in adequate incentives for action. Against this background, the purpose of this paper is to provide an overview of alternative instruments and interactions across them, within the context of a well-defined theoretical framework for thinking about climate policy design that explicitly takes into account political economy considerations. The analysis considers instruments available at both international and national levels.

2. Depending on its environmental objective, climate policy will need to focus not only on mitigation but also adaptation. ${ }^{2}$ Here, in light of widespread acceptance of the need to curb greenhouse gas (GHG) emissions with respect to a "business-as-usual" (BAU) scenario, and given that international negotiations for a post-Kyoto agreement are bound to focus primarily on mitigation, the analysis restricts itself to instruments aimed at reducing GHG emissions. The paper only briefly touches upon existing policies that distort the incentives from mitigation instruments, such as energy subsidies, barriers to international trade in emissions-reducing technologies, or lack of protection of property rights leading to deforestation in a number of developing countries. Also, the paper essentially takes as given the climate mitigation objective itself, except when exploring the extent to which uncertainty about this objective could affect policy design. In other words, the emphasis is more on the cost-effectiveness than on the efficiency of alternative climate policy options, since the latter would imply optimising across both the GHG emissions path and the instruments required to achieve it. Still, it should be borne in mind that policy choices may need to reflect not only cost-effectiveness considerations but also the ambition, nature and horizon of climate mitigation objectives themselves. For instance, available research suggests that only a narrow range of policy combinations may allow most ambitious targets to be met (see e.g. Gupta et al. 2007).

The author is a senior economist in the Structural Policy Analysis Division of the OECD Economics Department. He would like to thank Jan Corfee-Morlot, Jane Ellis, Jorgen Elmeskov, Stéphanie Jamet, Helen Mountford, Giuseppe Nicoletti and Jean-Luc Schneider for useful comments on an earlier draft, as well as all participants to the NERO/OECD Workshop on "The Economics of Climate Change" held in OECD headquarters on 12 march 2008. Special thanks go to Irene Sinha for technical preparation The author retains full responsibility for errors or omissions.

2 Climate policy might even focus on so-called "geo-engineering", or "solar radiation management", which may be loosely defined as any attempt to inject into the atmosphere substances (e.g. sulphur) to offset the global warming effects of GHGs. It has been argued that adaptation and geo-engineering, along with mitigation, could be part of an international climate policy agreement, given the theoretical case for equalising marginal costs across each of these alternative options to address climate change (see e.g. Barrett, 2007; Schelling, 2007). 
3. The remainder of this paper is structured as follows. Section 1 sets up a simple framework for thinking about climate mitigation policy design, emphasising a number of criteria any cost-effective (set of) instrument(s) should meet. Section 2 explores the extent to which the main instruments available to reduce GHG emissions (taxes, tradable permits - including permit trading at the sectoral level in the context of sectoral agreements, information instruments and command-and-control approaches, technology-support policies and voluntary agreements) are likely, in practice, to meet these criteria. Section 3 highlights possible interactions across mitigation instruments - including both complementarities to address multiple market failures and potential overlaps - as well interactions between mitigation instruments and existing policies in other areas. Section 4 sums up the main findings.

\subsection{A simple framework for thinking about climate mitigation policy instruments}

4. The final goal of an international climate policy framework is to minimise the overall economic cost of achieving any given climate mitigation objective. To this end, an ideal set of instrument(s) would meet three broad criteria (Table 1):

- Equalise marginal abatement costs across all emission sources in order to fully exploit existing opportunities for low-cost GHG emission reductions. ${ }^{3}$ This requires the instrument to be costeffective per se but also to be applied as widely as possible across countries, sectors and GHGs. The latter condition can only be met if sufficient political incentives exist for adoption and compliance both across and within countries.

- Foster an efficient level of innovation and diffusion of GHG emissions-reducing technologies in order to lower future marginal abatement costs. For an environmental problem which is of great magnitude (in terms of overall mitigation costs) and has a very long time horizon, such as climate change, this criterion plays an important role in assessing alternative policy instruments (Parry et al. 2003). An effective policy framework should provide adequate R\&D and technology diffusion incentives.

- Cope effectively with risks and uncertainties, i.e. the instrument should be responsive to risks and uncertainties surrounding both climate change and abatement costs.

5. In order to achieve these three objectives, a wide range of market imperfections needs to be overcome (Table 1). A number of these are likely to prevent the equalisation of marginal abatement costs across emission sources:

- Perhaps the most obvious market imperfection in this regard relates to the global public good nature of climate. The resulting free rider problem makes it inherently difficult for any environmentally-effective policy framework - i.e. one that is able to reach any particular climate mitigation target - to achieve wide coverage of emitters.

- Monitoring and enforcement costs. These can be large for certain emission sources such as, for instance, deforestation, methane emissions resulting from pipeline leakage etc.

- Information problems. Imperfectly informed households and firms may act inefficiently even if faced with adequate incentives. For example, it may be costly for households to monitor and,

GHG emissions usually induce "co-externalities", e.g. in terms of local pollution, which, unlike global warming, typically differ depending on the GHG-emitting activity and its geographical location. In this context, policy should seek marginal abatement cost equalisation across all GHG emission sources only to the extent that co-externalities can be addressed optimally through other instruments. 
therefore, to optimise energy consumption by electrical appliances. As well, the energy efficiency of buildings may be hampered by divergent incentives and asymmetric information between landlords and tenants.

- Capital market imperfections. These may, for instance, affect the ability of households and small firms to invest into profitable energy-savings equipment that has high "upfront" costs but low running costs.

Table 1. A simple framework for assessing policy options to reduce GHG emissions

\begin{tabular}{|c|c|c|c|}
\hline $\begin{array}{l}\text { Final policy } \\
\text { objective }\end{array}$ & $\begin{array}{l}\text { Intermediate } \\
\text { policy objectives }\end{array}$ & $\begin{array}{l}\text { Lower-level policy } \\
\text { assessment criteria }\end{array}$ & Market imperfections to be addressed \\
\hline \multirow[t]{3}{*}{$\begin{array}{l}\text { Set up a cost- } \\
\text { effective } \\
\text { international } \\
\text { climate policy } \\
\text { framework, i.e. } \\
\text { minimise the } \\
\text { overall } \\
\text { economic cost of } \\
\text { achieving a } \\
\text { given climate } \\
\text { mitigation } \\
\text { objective }\end{array}$} & $\begin{array}{l}\text { Tend towards } \\
\text { equal marginal } \\
\text { abatement costs } \\
\text { across all existing } \\
\text { GHG emission } \\
\text { sources }\end{array}$ & $\begin{array}{l}\text { - Cost-effectiveness of the (set } \\
\text { of) instrument(s) per se } \\
\text { - Country and activity } \\
\text { coverage, i.e. adoption and } \\
\text { compliance incentives for all } \\
\text { emitters both across and } \\
\text { within countries }\end{array}$ & $\begin{array}{l}\text { - The global public good nature of climate } \\
\text { creates a free-rider problem } \\
\text { - Monitoring and enforcement costs can be } \\
\text { large for some emission sources } \\
\text { - Information problems may prevent some } \\
\text { cheap abatement opportunities from being } \\
\text { exploited } \\
\text { - Emitters' power in their output market (e.g. } \\
\text { in the energy sector) and pre-existing } \\
\text { policies (e.g. fuel taxes and subsidies) can } \\
\text { distort the incentive effects of climate } \\
\text { mitigation instruments }\end{array}$ \\
\hline & $\begin{array}{l}\text { Foster innovation } \\
\text { and diffusion of } \\
\text { GHG emissions- } \\
\text { reducing } \\
\text { technologies }\end{array}$ & $\begin{array}{l}\text { - Strength of R\&D incentives } \\
\text { - Strength of technology } \\
\text { diffusion incentives }\end{array}$ & $\begin{array}{l}\text { - Appropriation by inventors of the full } \\
\text { social benefits of innovation is inherently } \\
\text { imperfect } \\
\text { - Adoption of existing technologies entails } \\
\text { positive externalities through learning by } \\
\text { doing and using } \\
\text { - Due to lack of credible commitment } \\
\text { devices, innovation and adoption incentives } \\
\text { are politically uncertain and even time- } \\
\text { inconsistent. } \\
\text { - Capital market imperfections may act as } \\
\text { adoption barriers, e.g. deterring households } \\
\text { and small firms from investing into energy- } \\
\text { savings equipment }\end{array}$ \\
\hline & $\begin{array}{l}\text { Cope effectively } \\
\text { with risks and } \\
\text { uncertainties } \\
\text { surrounding both } \\
\text { climate change } \\
\text { and abatement } \\
\text { costs }\end{array}$ & $\begin{array}{l}\text { - Responsiveness to risks and } \\
\text { uncertainties surrounding } \\
\text { climate change } \\
\text { - Responsiveness to risks and } \\
\text { uncertainties surrounding } \\
\text { abatement costs }\end{array}$ & $\begin{array}{l}\text { - Information regarding climate change } \\
\text { damages and abatement costs is incomplete }\end{array}$ \\
\hline
\end{tabular}


Other market distortions, while not necessarily preventing the equalisation of marginal abatement costs across emission sources, may still undermine the cost effectiveness of climate mitigation policy. This is the case of emitters' power in their output markets, not least in the energy sector, for example. The presence of pre-existing distortions (e.g. fuel taxes and subsidies) also forces climate policy to operate in a "secondbest" world. To the extent that it is politically difficult to fully remove such distortions, this may have an impact on the choice and/or design of instruments.

6. Innovation and diffusion of GHG emissions-reducing technologies are also subject to market imperfections. Market failures affect innovation and diffusion in general. In particular, knowledge spillovers are likely to induce firms to invest less in R\&D than would be socially desirable. While intellectual property rights (IPRs) in principle deal with this issue, they are often imperfect in practice, so that private inventors are not always able to capture the full social benefits from their innovation. Likewise, adoption spillovers such as learning by doing and using or network externalities cannot be fully captured by firms, thereby slowing the speed of diffusion of new technologies. Finally, asymmetric information between the firm and potential investors regarding the future returns from $R \& D$ and/or adoption of existing technologies may hamper its ability to raise capital for such activities.

7. Market failures affecting innovation and technology diffusion may be magnified in the area of climate change mitigation. In particular:

- The gap between social and private expected returns from $R \& D$ and adoption of existing technologies may be amplified by the political uncertainty surrounding the characteristics, and even the existence, of future climate policy, which in turn fundamentally reflects the lack of credible devices through which current governments can commit future ones. ${ }^{4}$ The commitment issue is often less acute in other public policy areas, either because their time scale is shorter or because policies are better established. Climate policy is not only uncertain but may even be time-inconsistent, insofar as governments may be under pressure to ease the policy a posteriori, once irreversible investments in $\mathrm{R} \& \mathrm{D}$ and new equipment are made. ${ }^{5}$.

- The country and/or sector coverage of price-based instruments is unlikely to be comprehensive at least over the medium run, thereby further raising the gap between social and private returns, and providing a "second-best" case for R\&D policies.

- Given the potentially large welfare consequences of any major breakthrough in technological progress, e.g. in the area of electricity production, the strong protection of IPRs may be insufficiently credible to private investors, who may expect governments to deprive them of any major innovation rent a posteriori. ${ }^{6}$

- Specific market failures and policy distortions in the electricity sector may explain low levels of $R \& D$ compared with other industries. In particular, already installed infrastructure creates network effects that may act as entry barriers to new technologies, thereby discouraging research. For instance, most national grids would not be suited to receive electricity from many small renewable electricity sources, while large scale renewable may also encounter problems if

\footnotetext{
$4 \quad$ It should be stressed that unlike such political uncertainty, economic uncertainty does not in general represent a market failure.

$5 \quad$ See e.g. Kennedy and Laplante (1999).

6 Such concerns have been put forward as an explanation for low private research on vaccines against major worldwide diseases such as malaria, tuberculosis or HIV (Kremer, 2001a, 2001b).
} 
located too far from existing grids. ${ }^{7}$ Along the same lines, the cumulative nature of knowledge may increase uncertainty about returns to $R \& D$. This is because the ultimate penetration of any path-breaking innovation hinges more crucially than in other sectors on a series of additional incremental innovations and learning gains, which are largely unpredictable ex-ante (see e.g. Stern, 2007, Chapter 16). Finally, low market competition and distortions such as fossil fuel subsidies may also contribute to keep R\&D spending low in the electricity sector.

8. Finally, as regards the need to cope effectively with risks and uncertainties surrounding both climate change and abatement costs, the market imperfection to be addressed is the incompleteness of available information. Uncertainty compounds at many levels. There is uncertainty surrounding future economic growth, the links between economic growth and GHG emissions, the climate effects of GHG emissions and the damages from climate change. Furthermore, there is a non-negligible, but yet largely unknown, probability of large and irreversible consequences from climate change. ${ }^{8}$ This raises a major challenge for policy, in a context where there are long lags between action and its mitigating impact on climate change.

\section{Assessing the cost effectiveness of available climate mitigation policy instruments}

9. The multiplicity of market imperfections to be addressed makes it unlikely that cost-effective climate mitigation can be achieved through a single policy instrument. This section reviews how each of the most commonly available instruments performs with respect to the assessment criteria developed above. Possible options which have been put forward in the literature to remedy, at least in part, their weaknesses are also discussed.

\subsection{GHG emission taxes}

\section{Intrinsic cost-effectiveness}

10. A corrective tax on the global negative externality associated with GHG emissions is a straightforward instrument available to achieve cost-effective climate mitigation. ${ }^{9}$ In the absence of any other market failure, a global tax on GHG emissions - or, equally, fully harmonised domestic GHG emission taxes - would be expected to induce all emitters to equalise marginal abatement costs to the level of the tax, thereby ensuring that the cheaper abatement options are fully exhausted. From this strict perspective, a tax instrument meets the criterion of intrinsic cost-effectiveness, sometimes called the "static efficiency" property of the tax.

11. In practice, administration and compliance also shape the cost-effectiveness of the tax. Such costs are usually lower under a tax than under most alternative instruments, at least if carbon taxation is applied

$7 \quad$ Network effects also exist in road transport, where high penetration of low-carbon technologies (e.g. electricity and hydrogen-fuel-cell vehicles, biofuels) would likely require new infrastructure.

The implications of such a "structural" uncertainty for the economic analysis of low-probability highimpact events are discussed in Weitzman (2007).

The notion of a corrective tax on pollution and negative externalities more broadly dates back at least to Pigou (1920). It should be noted that a carbon tax per se is not a perfect proxy for a tax on GHG emissions, since only the latter provides incentives to reduce GHG emissions through ways other than reducing the use of carbon-based inputs. Discussions of a global GHG emissions tax often assume that some tax credits would be provided to activities that remove GHGs from the atmosphere, such as forestation or carbon capture and storage. 
upstream to the wholesale use of fossil fuels. ${ }^{10}$ Nevertheless, based on a variety of country case studies in the area of industrial air pollution control, Blackman and Harrington (2000) argue that lower-income countries may lack the institutional capability to enforce it, especially under the indirect and intermittent methods that are typically used to monitor GHG emissions. As well, the way in which revenues are recycled matters. In theory, the more revenues are offset by a reduction in most distorsive taxes, the greater the cost effectiveness of the scheme - the so-called "double-dividend" from corrective taxes on pollution. ${ }^{11}$ In practice, as discussed below, this principle may conflict with the need to build up local political support for the tax, which is also needed to ensure wide coverage and may call for a different allocation of the proceeds from the tax.

12. More fundamentally, the fact that a GHG emissions tax addresses only one market imperfection albeit the main one - undermines cost effectiveness: ${ }^{12}$

- High costs of monitoring certain emission sources either raise tax collection costs or, if the emissions concerned go untaxed, prevent potentially cheap abatement options from being exploited.

- Likewise, information failures are not addressed by a GHG emissions tax and may, therefore, prevent full equalisation of marginal abatement costs.

- The power of emitters in their output markets, not least in the energy sector, reduces the welfare gain from the GHG emissions tax. This results from the welfare loss from reduced output in the monopolistic sector from an initial level which is already below what would be socially desirable (Buchanan, 1969; Cropper and Oates, 1992). Likewise, the cost-effectiveness of a tax - or, for that matter of virtually any climate mitigation instrument - is undermined by other policies that distort its substitution incentives, including in particular fiscal incentives to energy production/use and agricultural subsidies. ${ }^{13}$ Finally, public or quasi-public enterprises may not face strong incentives to respond adequately to the tax, partly due to objectives other than profitmaximisation and softer budget constraints than in the private sector.

However, one potential drawback of pricing carbon upstream is to provide no incentive for carbon capture downstream. Only carbon capture upstream (e.g. by electricity producers) could be taken into account, although it may raise some monitoring problems since emissions are no longer linked directly to fossil fuel consumption.

See e.g. De Mooij (1999), Goulder (1995), Goulder et al. (1999), Pezzy and Park (1998). However, one limit to the argument is that major tax distortions could still be eliminated independently from carbon tax revenues, e.g. by changing the tax structure. Also, cutting distortions may not be the best possible way to use the financial room of manoeuvre from carbon tax revenues. Subsidising R\&D in emissions-reducing technologies may actually be better policy (see below).

There are also concerns that because fossil fuel reserves are exhaustible, producers may react to the expected path of the tax - and that of any demand-reducing policy more broadly - in such a way that undermines its environmental and/or cost effectiveness. Indeed, some expected gradual increase in the tax rate - the so-called "climate policy ramp" advocated by most economists in the field - may induce fossil fuel producers to speed up extraction so as to benefit from higher revenues today (Sinn, 2007). This would increase emissions and/or force governments to opt for a higher initial tax rate than initially desired.

Policies that discourage GHG emissions (e.g. fuel or electricity consumption taxes) will also usually undermine the cost-effectiveness of a GHG emissions tax. Interactions across different emissions-reducing policies are studied in detail in the next section of this paper. 
ECO/WKP(2008)44

\section{Adoption and compliance incentives}

13. Covering the largest possible share of global GHG emissions is perhaps the most important precondition for a global GHG emissions tax to be cost-effective. ${ }^{14}$ It is, therefore, of prime importance to assess the political incentives for governments to adopt such a tax and to enforce it domestically. In this respect, international competitiveness and income distribution concerns - valid or not - have often been perceived as major obstacles to implementation.

14. A global GHG emissions tax has at least two attractive political features. First, it raises only minimal legal issues, as it can be implemented simply through national legal systems and institutions, without any strong need for harmonisation or the creation of a new international institution. Second, partly as a result of this legal simplicity, it is flexible. A country can quickly join (or withdraw) without any need for a round of international negotiations, as it just needs to create a new national tax set equal to the global carbon tax rate. Likewise, two (groups of) countries can merge their distinct carbon tax schemes simply by harmonising the tax rates. ${ }^{15}$

15. Nevertheless, these few political strengths are more than offset by several weaknesses, which explain why a global tax does not rank high on policymakers' agenda:

- At the international level, the immediate economic impact of the tax would, in general, be proportionately greater on developing countries, reflecting essentially the higher carbon-intensity of their economies. This deters developing countries from adopting the tax, and may also be seen as not conforming to principles of distributional equity.

- One possible answer to this issue would be an international agreement specifying lump-sum payments - or alternatively transfers of a share of future international tax revenues - from developed to developing countries. However, it is unclear whether electorates in developed countries would support the large, transparent payments that would likely be involved. Also, such transfers might raise governance issues in recipient countries.

- Another option would be to impose countervailing duties on carbon-intensive imports from nonparticipating countries (see e.g. Stiglitz, 2006). These would reduce the risk of emissions leakage and provide some incentives to adopt the tax. However, it is unclear whether they would be fully credible, since adoption would entail large costs for consumers in participating countries. As well, they would not address the distributional issue that underlies the political disincentives for developing countries to join in. In this context, they might trigger retaliation by affected trade

The loss of cost-effectiveness and/or environmental integrity associated with incomplete coverage depends on the magnitude of emissions leakage. Leakage arises when abatement by co-operating entities alters world relative prices in ways that lead to an increase in emissions by non-co-operating entities. These entities are typically countries although, in principle, they could also be industries or even firms. There are two main channels through which emissions leakage arises. First, the loss of international competitiveness of carbon-intensive industries from co-operating countries induces some reallocation of output towards non-co-operating countries. Second, lower demand for carbon-intensive fuels reduces their world price, thereby raising demand. Ultimately, the practical relevance of leakage hinges to a large extent on the supply elasticity of carbon.

In practice, two issues may complicate somewhat the harmonisation of carbon taxes across countries. First, tax exemptions for certain industries may be granted in some countries but not in others. Second, different countries may levy the tax at different stages of the carbon supply chain, with the risk that some emissions may be priced twice or, on the contrary, could avoid taxation. For instance, in order to avoid double taxing, a country with an upstream tax on fossil fuel suppliers would have to exempt from the tax all fuels exported to countries that apply a similar tax rate downstream on fossil fuel users. 
partners, rather than by greater participation. Furthermore, it is not certain that the current World Trade Organisation's (WTO) legal framework provides grounds for using such countervailing duties (OECD, 2006; Perez, 2007). In order to meet some of these concerns, Perez (2007) advocates a generalised system of predictable, permanently applied environmental tariffs. In any event, import tariffs could entail large administrative costs and would run the risks of capture by lobbies. Finally, and perhaps most importantly, while they may address competitiveness concerns, they do little to address the carbon leakage that occurs through the fall in world fossil fuel prices - which in turn results from lower demand for carbon-intensive fuels in participating countries.

- At the domestic level, the costs from a GHG emissions tax are highly transparent, occur immediately and are concentrated on relatively well-organised groups. By contrast, its benefits accrue to no clearly identifiable agent, are widely dispersed and are to be reaped only far in the future. Furthermore, implementing a GHG emissions tax does not build up any political constituency with a strong interest in maintaining the tax. Under such conditions, the political economy literature suggests that affected groups will be in a position to lobby successfully against the tax (e.g. Olson, 1965). Alternatively, as suggested by Stavins (1997), they may lobby a posteriori in favour of offsetting measures (e.g. taxes on substitutes to carbon or subsidies to complements to carbon), thereby undermining de facto any international tax harmonisation agreement. Another political obstacle to implementation is the regressive nature of a carbon tax, which raises genuine national income distribution concerns. While this issue can, at least in principle, be addressed via the tax-benefit system, this option is not always available in lowerincome countries with weaker social policy settings.

- In principle, lack of domestic support for a GHG emissions tax can be mitigated through partial redistribution of the tax revenues to affected industries. Nevertheless, apart from reducing costeffectiveness (OECD, 2007a), revenue-recycling may be seen as insufficiently credible in practice. In contrast with the tax, compensatory schemes may be perceived as transitory, as governments cannot easily commit to maintaining them beyond the current budget horizon. From this strict perspective, a single, large, lump-sum payment upon implementation might be expected to facilitate the adoption of the tax.

\section{$R \& D$ and technology diffusion incentives}

16. With a GHG emissions tax, emitters face a continuing incentive for emissions-reducing innovation. This is the so-called "dynamic efficiency" property of taxes and market-based mechanisms in general. Furthermore, at least in principle, a tax provides a stable price signal to investors since the only source of (unexpected) carbon price volatility should come from unforeseen political adjustments to the tax rate. This is important in view of the long investment horizons that are typical of climate mitigation problems, since even a small amount of uncertainty can severely reduce expected returns from investment in such a context.

17. However, a carbon tax addresses only one, and not all the market imperfections undermining $\mathrm{R} \& \mathrm{D}$ and technology diffusion. The latter would, therefore, be expected to remain sub-optimal even if a fully credible tax could be implemented. As already noted, a carbon tax may also be perceived to have an uncertain political future and even to be time-inconsistent. While suggestions to fix this problem have surfaced recently in economic literature, none seems fully convincing. One option would be to use tax earmarking ${ }^{16}$ as a commitment device (Marsiliani and Renström, 2000). However, this argument should be weighed against the loss of cost-effectiveness associated with earmarking. Alternatively, drawing a parallel 
with the monetary policy literature, the time-inconsistency problem may be addressed by delegating the power to set the GHG emissions' tax rate to an independent climate policy authority, akin to a "conservative" central banker (Helm et al. 2004; Helm, 2005). However, ensuring that such an institution retains full independence may be easier in a national, rather than in an international, context. ${ }^{17}$

\section{Ability to cope effectively with risk and uncertainty}

18. In the short run, by setting the marginal cost of reducing GHG emissions, a tax gives some certainty about overall abatement costs at the price of uncertainty about total emissions. Insofar as abatement costs are unknown to the policymaker and/or can be subject to shocks (e.g. to economic growth, energy supply or technology) after policy has been set, a tax has been shown to be a more efficient pollution control device than a quantity instrument, provided the marginal climate impacts from lower emissions are less sensitive to emission levels than marginal abatement costs, and vice versa (Weitzman, 1974). ${ }^{18}$ In other words, a tax should be preferred to a quantity instrument when the marginal (climate) damage curve is "flatter" than the marginal cost curve. This condition is likely to be met in the case of climate change, because the marginal damage from higher-than-expected emissions is relatively constant in the short run, since only cumulative - not current - emissions matter for the climate. This is true at least in the current situation where GHG concentration levels remain significantly below thresholds that might trigger extreme and irreversible events, such as for instance the melting of the Greenland and West Antarctic ice sheets. In this context, under a tax the overall economic cost of unexpected shocks to (marginal) abatement costs will be mitigated by (less harmful) increases in short-run emissions, while under an inflexible cap-and-trade scheme emissions will remain fixed and overall economic costs will be higher. ${ }^{19}$ Recent research suggests that this short-run efficiency gain from taxes could be large in practice, under reasonable assumptions about actual marginal damage and cost curves (Hoel and Karp, 2001; Newell and Pizer, 2003, Pizer, 2002). ${ }^{20}$

17 Another option which has been suggested to address at least partly the time consistency problem would be to start with a more aggressive emissions-reducing policy than would otherwise be optimal (Frankel, 2007). However, for reasons noted previously, it is unclear whether political incentives to follow such a path would be sufficiently strong.

It should be stressed that only shocks to (marginal) abatement costs typically matter in this context. Shocks to (marginal) damages from emissions will usually entail the same welfare loss under a price and a quantity instrument, since emissions will remain unchanged in both cases. One exception to this general rule is when shocks to (marginal) abatement costs and damages are statistically correlated. In particular, positive correlation would tend to favour a quantity over a price instrument, ceteris paribus, and, if strong enough, may even reverse the conventional finding that price instruments should be preferred (Stavins, 1996). However, it is unclear whether such a positive correlation is plausible in practice in the case of climate change mitigation.

In the case of segmented (unlinked) national policies, the advantages of taxation over a simple quantity instrument would be greatest in those countries where uncertainty about abatement costs is highest (e.g. in developing countries, where policymakers' information about emissions and abatement options may be low).

One limitation of this literature is to assume that firms take their marginal abatement cost curve, and therefore implicitly their abatement technology, as given. In practice, the nature of the emissions control instrument may shape firms' technological choices in a way that reduces the superiority of price over quantity instruments (Krysiak, 2008). Ceteris paribus, a firm that operates under an emissions tax would opt for a flexible technology that enables to accommodate possible shocks to (marginal) costs through changes in the quantity of emissions. For example, the quantity of emissions released by a coal-fired power plant with carbon capture and storage can be adjusted more easily than that of a nuclear power plant. Since more flexible technologies correspond to flatter marginal cost curves, technological choice tends to reduce the advantage of price over quantity instruments. 
19. Over the longer term, the uncertainty problem that policy needs to address becomes of a somewhat different nature. In order to reach any given mitigation target, a tax would need to be revised on a regular basis in view of environmental outcomes. As well, given the uncertainties and irreversibilities affecting both climate change and the costs of mitigation policies, the mitigation target itself may need to change. Hence, an adjustable tax would provide no certainty over longer-run abatement costs. Therefore, a key challenge would be to design the tax in a way that its future changes in response to environmental outcomes and mitigation costs remain sufficiently predictable, so as to limit possible detrimental effects on R\&D and technology adoption incentives. Built-in (ex-ante) adjustment rules might go some way towards addressing this trade-off between policy flexibility and predictability.

\subsection{Tradable emission permits}

\section{Intrinsic cost-effectiveness}

20. While a global GHG emissions tax so far remains little more than a theoretical policy option, the international community has de facto made some progress towards the implementation of an international emissions trading scheme, albeit a highly fragmented one. In principle, under perfect competition and in the absence of uncertainty, a tradable permit system and a tax are both cost-effective, and they are in fact equivalent. As well, provided permits are fully auctioned, both instruments have similar potential to yield a "double-dividend" from mitigation. Finally, both deal with only one among the several market imperfections to be addressed by mitigation policies.

21. While there is little empirical evidence about the magnitude of transaction costs in GHG emission permit markets, there is a general suspicion that they can be larger than those from a tax (OECD, 2007a). This is especially the case for downstream schemes, under which multiple small emission sources may be covered at a significant cost or even be exempted, thereby hampering the overall cost-effectiveness of the system. Downstream schemes also raise practical implementation problems in the absence of reliable initial data on emissions. However, insofar as many of the transaction costs associated with permit markets reflect insufficient market liquidity, moving towards a truly integrated international permit trading scheme would be expected to improve cost-effectiveness, ${ }^{21}$ although this gain should be weighed against the cost of enforcing a policy that crosses national jurisdictions. Also, pricing emissions from diffuse sources - e.g. from agriculture, where many small emitters operate - may be harder to achieve through tradable permits than through taxes. Even leaving this specific issue aside, setting up a permit trading scheme may be even more challenging for developing countries than collecting an emissions tax (through already-established tax collection institutions), and may also be more vulnerable to capture by lobbies (Blackman and Harrington, 2000).

22. Market power in the permit market can also undermine cost-effectiveness. A monopolistic permit seller would drive a wedge between the permit price and its own marginal abatement cost, thereby breaking the rule of marginal abatement cost equalisation across emitters, with the consequence that permit buyers would be forced to abate more at a higher cost. Such concerns matter only insofar as permits can be stored for future use - e.g. in the context of multiphase programmes - and trading can take place at the level of sovereign states, given that even large firms would be unlikely to have enough power to affect prices in an international permit market. The market power issue arose in the context of the Kyoto Protocol, with several papers showing that a cartel formed by transition countries - including, in particular,

In particular, the costs of searching for information about permit prices, finding trading partners and negotiating with them can be expected to decline strongly with market size. See Kerr and Maré (1998) for some taxonomy of transaction costs affecting permit markets. These authors estimated that transaction costs led to an over 10\% efficiency loss from trading in the US market for lead permits during the lead phase down from 1982 to 1987. 
ECO/WKP(2008)44

Russia and Ukraine - would lower the gains from the international trade mechanism (Maeda, 2003; OECD, 1999).

\section{Adoption and compliance incentives}

23. While facing a broadly similar political challenge as a tax, namely the difficulty to overcome fundamental lack of adoption and enforcement incentives both across and within countries, a permit trading system has its own strengths and weaknesses. A basic strength is that a number of national and regional schemes already exist, as well as flexibility mechanisms that enable emission commitments under these schemes to be met by undertaking project-based emission reductions in other geographical areas, such as the Clean Development Mechanism of the Kyoto Protocol. There is, therefore, some basis for developing linkages between existing schemes and scaling-up and improving the use of flexibility mechanisms, subject to dealing with integrity concerns and minimising transaction and monitoring costs.

24. Yet, permit trading raises a number of political challenges. Unlike a tax, a truly international scheme cannot easily be implemented through existing legal frameworks and institutions. In practice, existing national and regional schemes operate under fairly heterogeneous rules, thereby hindering possible future integration (see e.g. Capoor and Ambrosi, 2006; Ellis and Tirpak, 2006). The system therefore lacks the flexibility to incorporate quickly new participating countries. It may also be somewhat more vulnerable to lax monitoring and enforcement in some participating countries. ${ }^{22}$ Even abstracting from monitoring and enforcement issues, linking to other schemes may raise a number of concerns: $i$ ) expectations of linking might induce national policy makers to engage into strategic behavior, e.g. by setting a less stringent emission cap - and therefore a lower carbon price - today, in order to benefit from net capital inflows upon linking to more stringent schemes in the future; ii) design features that make the emission cap more flexible in one particular country (e.g. banking and/or borrowing allowances, price caps and/or floors: see below) would de facto become available to emitters in all other countries once schemes are linked; iii) linking raises a communication challenge in those areas where local emission targets exist, since it implies a loss of sovereignty over both the quantity and the price of emissions.

25. In practice, however, these weaknesses of permit trading may be more than offset by a number of politically attractive features at both international and domestic levels. At the international level, any income transfers required to encourage large developing countries to join in may be more acceptable to the electorates of developed countries if they take place indirectly, through permit allocation, rather than through direct income transfers. At a domestic level, permit trading has the following advantages over a tax:

- It provides direct flexibility to build up political support for the scheme through permit allocation rules. This largely explains the predominance of grandfathering in practice (see e.g. OECD, 2007a). Some limited degree of "grandfathering" may also be justified as a way to compensate holders of existing assets for the (unexpected) costs they incur with the implementation of the scheme (Johnston, 2006). However, it compromises the cost-effectiveness of the scheme over the longer run - including by distorting industry dynamics, i.e. entry and exit incentives. It also raises

22 Lax monitoring by one country may raise bigger concerns under a permit scheme than under a tax. Under cap-and-trade, laxity in one (large) country reduces emission prices, thereby undermining emission reduction incentives in all other countries. By contrast, under a set of harmonised taxes, laxity in one country does not affect emission prices and reduction incentives in other countries. Furthermore, insofar as a permit trading scheme is more difficult to monitor and enforce than a tax in developing countries, developed countries may be more concerned about linking permit systems than about harmonising emission taxes. 
equity concerns, since it provides "windfall profits" to emitters financed by consumers. There is, therefore, a strong case for limiting "grandfathering" both in scope and time.

- At a deeper level, establishing a permit market creates a well-identified domestic constituency permit holders - with a strong financial interest in enforcing the policy in the future, at least if permits have a sufficiently long horizon.

- Permit allocation rules have also been used to address international competitiveness and/or national income distribution concerns. This has been the case - even though any effects in these areas are likely to be limited and short-lived, since marginal emission costs are ultimately passed onto consumers, irrespective of permit allocation rules. Nevertheless, permit trading has also been put forward as a primary tool to address international competitiveness concerns within the context of government-led international sectoral agreements. Insofar as some part of the leakage risk is concentrated on a few large energy-intensive sectors, relatively immune to competition from other sectors and dominated by a small number of participants (some types of ceramic, aluminium, iron, steel), international sectoral agreements may indeed be easier to achieve than a global agreement, and could usefully complement domestic emissions-reducing policies. They could include sectoral targets that would be achieved at minimum cost through sectoral permit trading, assuming effective monitoring and enforcement can be achieved in developing countries. However, while offering a political way forward, sectoral agreements would significantly raise the cost of achieving any overall emissions reduction objective, compared with more comprehensive policies. This is because they do not allow cheap abatement opportunities through trading across sectors to be exploited. Furthermore, sectoral approaches can come in different forms, most of which might be significantly less effective than sectoral permit trading (Box 1).

- Finally, unlike a tax, international permit trading enables some degree of subsidiarity to be maintained in implementation at the country level. An international permit trading agreement between governments may indeed be consistent with a variety of policy arrangements to meet emission objectives within each country. ${ }^{23}$

\section{Box 1. A brief overview of international sectoral approaches to address GHG mitigation}

There is growing interest in incorporating some sort of sectoral approach into a post-2012 climate policy package. Indeed, the Bali Action Plan agreed by all countries in December 2007 indicates that it will consider "sectoral actions". There are many different possible forms that sectoral actions could take, and such actions could apply to developed and/or developing countries. As yet, no clear definition of what a sectoral approach or action encompasses has been agreed.

Possible forms of sectoral actions or approaches include inter alia (see e.g. Baron and Ellis, 2006; Ellis and Baron, 2005):

- A sectoral crediting mechanism, where a baseline is established for a sector as a whole, and trading can occur among firms if performance is better than the baseline.

- A global agreement (e.g. on GHG emissions or intensity) between industry and countries.

- A series of national policies targeting a specific sector, potentially with international co-ordination.

- A global, voluntary and unilateral action by a certain industry.

Depending on what form it takes, a sectoral action may be classified as a permit trading scheme (e.g. by implementing a sectoral crediting mechanism), a command-and-control approach (e.g. by implementing mandatory standards across a sector) or a technology-support policy (e.g. with industry in a sector voluntarily agreeing to implement best practice technology). Only a sectoral crediting mechanism would clearly imply permit trading, while

23 Depending on the nature of such arrangements, and in particular on whether international permits remain in the hands of governments or are allocated to national firms, market power in the international permit market may or may not be a concern. 
other sectoral approaches may or may not.

These different potential forms of sectoral actions vary in terms of their environmental effectiveness, their cost effectiveness, and the political incentives for adoption they provide. Practical barriers to implementing a sectoral approach may also arise in some cases. For example, data constraints can be significant in some developing countries. For any sectoral approach that involves trading, historical data and projections would be needed to establish a baseline against which trading can occur. If sufficient data for some key sectors or countries are not available, it could render this type of sectoral approach difficult to implement in the short term (or could generate large upfront costs and/or delays in order to gather the data). A sectoral approach involving crediting would also need clear links between the performance of individual plants and the level of credits it can generate within each country concerned. This may be best achieved if emission allowances within each country are allocated to individual firms ex-ante, rather than ex-post -as the latter option would lead to more uncertainty and lower incentives to reduce emissions ex-ante.

\section{$R \& D$ and technology diffusion incentives}

26. Permit trading has the same basic strengths and weaknesses as a tax with respect to providing adequate $\mathrm{R} \& \mathrm{D}$ and technology diffusion incentives. While neither a tax nor a permit trading scheme address the full range of market failures associated with the innovation and diffusion of new technologies, both are dynamically efficient, i.e. they give emitters continuing incentives to search for cheaper abatement options through both existing and new technologies. In practice, however, lack of certainty about the future carbon price and potential time-inconsistency may undermine to some extent these incentives.

27. Still, depending on whether and how they are expected to be revised in the future, taxes and permits may differ in several respects:

- In the absence of expected revisions, existing literature suggests that innovation and diffusion incentives may be lower under tradable permits than under a tax. First, expected carbon price volatility would be higher under a simple quantity instrument such as permit trading than under a tax. Insofar as R\&D and the adoption of new technologies generate sunk costs, this would be expected to further delay firms' decision to invest into emissions-reducing activities, ceteris paribus (Dixit and Pindyck, 1994). Including both a price cap and a price floor would help stabilise price expectations and boost R\&D incentives, however (Burtraw et al. 2006). ${ }^{24}$ Second, because the diffusion of new technologies is expected to lower the equilibrium price of emissions a posteriori under permit trading, individual adoption incentives may be lower ex-ante than under a tax (Box 2).

- In practice, both schemes are likely to need to be revised over time, to reflect evolving understanding of the level of desired stringency of the instrument as well as technological developments. Whether adjustable taxes yield greater innovation incentives than adjustable permits is likely to depend on the predictability of the revisions. In this regard, once markets are established and permits are allocated, the risk of arbitrary policy changes may be seen as lower under permit trading than under a tax. ${ }^{25}$ However, under a tax, firms have lower incentives to lobby against policy adjustments $a$ posteriori, thereby making policy changes more predictable ex-ante. This is because the optimal response of policymakers to cost-reducing technological change is to lower the tax rate, i.e. to reduce the costs imposed on firms. By contrast, the optimal response under tradable permits is to tighten the emissions cap, and thereby increase the permit price and the costs incurred by firms (Box 2).

By contrast, a price cap alone might actually lower $R \& D$ incentives by reducing the average expected price of emissions (Burtraw and Palmer, 2006).

Still, political uncertainty about the future price path of carbon may be higher ex ante under a system of fragmented domestic tradable permit schemes (with different prices to be harmonised in the future) than under a true international permit trading system. This suggests that speeding up the linking of existing schemes may contribute to improve not only static but also dynamic efficiency. 


\section{$\mathrm{ECO} / \mathrm{WKP}(2008) 44$}

\section{Box 2. Do R\&D and technology adoption incentives under GHG emission taxes and simple cap-and-trade schemes differ?}

While emission taxes and tradable permits have the same basic strengths and weaknesses in terms of providing adequate R\&D and technology adoption incentives, existing literature points to some differences. These depend on whether and how both policies are expected to be revised in the future.

A fixed tax is likely to provide greater incentives than a fixed cap-and-trade scheme, because of the so-called "abatement cost effect" (Denicolò, 1999; Keohane, 1999). ${ }^{1}$ For a given individual firm, the fact that other firms are expected to adopt the new technology reduces the expected permit price and, therefore, the expected cost savings from adopting the technology. By contrast, under a tax, the individual firm's incentive to adopt a new technology depends only on the level of the tax and not on other firms' behaviour. Parry (1998) finds that in practice, this superiority of taxes over permits is significant only as regards major innovations. In a more general theoretical framework, Fischer et al. (2003) find the welfare gains from taxes to always be larger than those from permits provided marginal environmental benefits from emission reductions are relatively flat (as is the case in the area of climate change) and there is no possibility for firms to imitate the patented technology.

Previous literature had argued that auctioned permits provided larger adoption incentives than taxes and free (grandfathered) permits (Milliman and Prince, 1989; Jung et al. 1996). This result reflected an "emissions payment effect", through firms that have to pay for permits can expect to gain from a fall in the permit price, while this effect is absent in the aggregate under free permits as the gains and losses to net buyers and sellers of permits cancel out. However, Keohane (1999) argues that in a competitive permit market, each firm enjoys the fall in the permit price regardless of whether it adopts the new technology. Because the gains from the fall in price are induced by aggregate adoption decisions, they do not affect individual adoption incentives.

Once allowance is made for the fact that both schemes are likely to be revised over time, it becomes less clear whether taxes provide greater innovation incentives than permits. One advantage of permits may be the lower perceived political risk of arbitrary policy adjustments, once permit markets are established and permits are allocated. One advantage of taxes is that firms will not have an incentive to lobby against policy adjustments a posteriori, thereby making such adjustments more predictable ex-ante (Milliman and Prince, 1989; Biglaiser et al. 1995).

The basic intuition for the latter finding is explained in the figure below. For a given time period, the optimal policy is to equalise the marginal damage from emissions and the marginal cost of a reduction in emissions. Denoting the marginal cost and damage curves $M C$ and $M D$, respectively, the optimal policy is to emit $Q$ a tonnes of carbon at price $\mathrm{Pa}$. This can be achieved either by a carbon tax $\mathrm{Pa}$, or through a permit trading scheme that sets an emissions cap $\mathrm{Qa}$. In both cases, the equilibrium is ( $\mathrm{Qa}, \mathrm{Pa}$ ) before innovation takes place. Innovation would be typically expected to shift the marginal cost curve MC downwards. In the absence of revision to the policy, the new equilibrium would be $(\mathrm{Qc}, \mathrm{Pa})$ under a tax and $(\mathrm{Qa}, \mathrm{Pb})$ under permit trading. However, none of these equilibria would be optimal, since marginal damages and marginal costs would differ. Therefore the policy maker would have an incentive to revise the policy to achieve the new optimum $(\mathrm{Qd}, \mathrm{Pd})$. Under a tax system, this would imply a reduction in the tax, from which firms would benefit. Under permit trading, this would imply a tightening of the cap and an increase in the emissions price, from which firms would lose, and which they are, therefore, likely to oppose. Because the outcome of such lobbying may be uncertain, policy revisions may be less predictable under permit trading than under a tax.

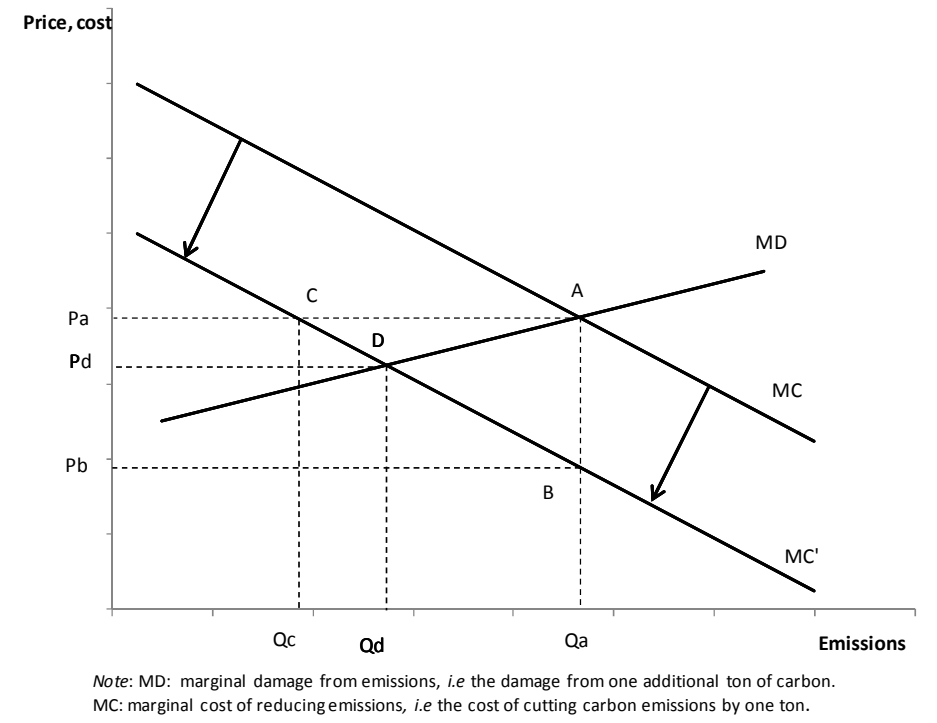


ECO/WKP(2008)44

\section{Ability to cope effectively with risk and uncertainty}

28. Compared with a tax, cap-and-trade yields more certain environmental outcomes at the cost of more uncertain economic costs. As already noted, this is not an efficient way of dealing with short-run uncertainty in the case of climate change, because the welfare consequences of unexpectedly high abatement costs are likely to be higher than those from unexpectedly high emissions. ${ }^{26}$ For example, under an international permit trading scheme with a set of fixed national targets, changes in country participation (e.g. the withdrawal of a major emitter) would induce large fluctuations in the carbon price and impose large costs on participating countries (under unchanged global emission objectives). This difference between taxes and permits may be less clear-cut over the longer run, however, if both instruments adjust on a regular basis in view of environmental or economic outcomes. In both cases, the key challenge over the longer run would be to set up a policy that responds to new information, but still does so in a predictable way in order to preserve $R \& D$ and technology adoption incentives. From this perspective, permit schemes may be more responsive than taxes. This is because any change in the expected path of policy - e.g. a larger than expected tightening of the emission reduction objective in the future, following a larger than expected rise in temperature in the recent past - would affect current emission prices, ${ }^{27}$ while under a tax prices would remain fixed until policy makers decide to reset them.

29. A number of options have been suggested in order to enhance the robustness of permit trading schemes to short-run cost uncertainty:

- One is to set a price floor in order to prevent the price of emissions from falling too low, i.e. too far below the marginal damage from emissions in the presence of short run shocks. ${ }^{28}$ This reduces the risk of large price fluctuations - of large price falls specifically - and thereby provides some of the advantages of a tax. A price floor may be particularly useful if emission caps are felt to be little responsive to (unexpected) good news about abatement costs, possibly as a result of political lobbying (see Box 2). ${ }^{29}$

- Another option is to allow inter-temporal flexibility in the timing of emission reductions, e.g. through banking provisions, which allow permits to be stored for future use in the context of multi-phase programmes. Banking is also likely to reduce the risk of large price fluctuations under general circumstances. ${ }^{30}$ It also makes sense from an environmental standpoint, since the

However, Montero (2005) shows that this weakness of quantity-based instruments diminishes and may even be reversed under imperfect emissions control. This is essentially because imperfect enforcement "softens" the quantity instrument, with some firms choosing not to comply when abatement costs prove to be higher than expected.

This would be the case at least if some flexibility is allowed in the timing of emissions, e.g. through banking and borrowing allowances.

One straightforward way to set a price floor would be for governments to auction a sizeable portion of the allowances, and to withhold allowances from the auction as needed to maintain that price. Also, in multiperiod schemes, future allocations could be reduced when current prices are deemed too low, which would raise current prices provided banking is allowed, ceteris paribus. The latter option has for instance been applied in the United States within the context of the 2005 Clean Air Interstate Rule on $\mathrm{SO}_{2}$ and $\mathrm{NO}_{\mathrm{X}}$ emissions.

Burtraw et al. (2006) argue that in the case of the US $\mathrm{SO}_{2}$ cap-and-trade scheme, lack of policy responsiveness to lower-than-expected abatement costs - i.e. lack of tightening of the emissions cap generated significant welfare losses in the 1990s, which could have been avoided with the existence of a price floor.

For example, lack of banking provisions seems to have amplified the large drop in the EU ETS permit price which took place in the Spring of 2006, following the release of lower-than-expected $\mathrm{CO}_{2}$ emission 
precise timing of emissions has in general little impact on the ultimate damage. As well, by allowing permits to be established over a sufficiently long horizon, banking may facilitate the emergence of forward markets. However, unlike a price floor, banking would not provide full certainty about the minimum price of emissions. Banking can be effective only insofar as individual emitters expect (discounted) future prices to be higher than the current price.

- Permit schemes may also include a price cap or "safety valve", i.e. a fixed maximum price at which the regulator commits to selling any excess number of permits demanded by participants Roberts and Spence (1976) have shown such hybrid quantity-price instruments to be preferable to simple quantity instruments under uncertainty about abatement costs,${ }^{31}$ and more recent research has confirmed this finding in the context of climate change (Pizer, 2002). ${ }^{32}$ McKibbin and Wilcoxen $(2002,2007)$ suggest that an internationally-co-ordinated system of hybrid national policies, each consisting of a fixed supply of long-term permits and a more flexible supply of short-term permits, would combine some of the strengths of price and quantity instruments, namely: $i$ ) like a tax, it would reduce short-run cost uncertainty, could be implemented readily through existing national institutions, and would allow straightforward linking across countries through short-run permit price harmonisation; ii) like a permit trading scheme, it would build up a clear constituency with a strong interest in maintaining the policy over the long-run.

- Yet another option to keep mitigation costs in check would be to set intensity (e.g. emissions per unit of output) rather than absolute targets (Marcu and Pizer, 2002; Kolstad, 2006; Gupta et al. 2007; Jotzo and Pezzey, 2007). One advantage of intensity targets is to allow automatic adjustment of emission objectives to unexpected shocks to economic growth which, along with genuine shocks to marginal abatement costs, represent one of the two main sources of uncertainty surrounding the overall cost of meeting an absolute emissions cap. However, intensity targets do not in general provide the best possible way to insure against short-run growth shocks, compared with a price cap (Quirion, 2005; Pizer, 2005) ${ }^{33}$ They may also entail higher administration and compliance costs than absolute targets (Dudek and Golub, 2003; Müller and MüllerFürstenberger, 2003). Finally, they need to be carefully designed in order to remain consistent

figures for the year 2005. Indeed, while the future price fell from over EUR 30 per ton of $\mathrm{CO}_{2}$ to about EUR 15 between the springs of 2006 and 2007, the spot price dropped from over EUR 30 to under EUR 1. By allowing participants to store permits for the second phase of the programme, banking would have supported the spot price (although it would have also reduced the environmental effectiveness of the EU ETS during the Kyoto period 2008-2012).

The authors find that under uncertainty about abatement costs, standard permit trading is inferior to a hybrid system in which firms have the option to pay a fee (an "escape" or "safety" valve) instead of buying permits when costs happen to be higher than expected.

Borrowing provisions - i.e. the possibility for an emitter to borrow permits - could also contribute to avoid large price spikes. However, unlike a price cap, they would be effective only insofar as emitters expect future prices to be lower than the current price (see e.g. Congressional Budget Office, 2008). They may also provide excessive incentives for emitters to defer emission reductions to the future, in a context where the stringency and even the existence of future climate policy may be uncertain.

The case for emission intensity targets fundamentally rests on the existence of a strong short-run link between emissions and GDP growth. In practice, however, this link is weakened by the negative short run correlation which also typically exists between emissions intensity and GDP growth (Pizer, 2005). Such a correlation implies that not only absolute but also relative emissions caps (i.e. the intensity targets themselves) relax when growth is high and tighten when growth is low. In other words, intensity targets would provide excessive insurance against growth shocks. Jotzo and Pezzey (2007) suggest to improve their insurance properties by tailoring them to the strength of each country's GDP-emissions linkage. 
with long-run stabilisation of GHG concentration, a minimum condition being that the rate of decline in emission intensity should exceed trend GDP growth (Kolstad, 2006).

- Finally, linking domestic schemes would be expected to mitigate the impact of shocks and thereby to reduce price volatility, even though shocks could become more frequent as the system is no longer immune to developments in other areas. For instance, the carbon price effect of unexpectedly high short-run economic growth in one country would be lower under linked trading schemes than under a smaller domestic system, all the more so as the country considered is small compared with the overall area covered through linking.

\subsection{Command-and-control (CAC) approaches}

30. Command-and-control (CAC) approaches denote regulatory instruments that dictate abatement decisions and fall in two broad categories: $i$ ) technology standards, which impose on emitters the use of specific abatement technologies; and, ii) performance standards, which set specific environmental targets to be met (e.g. a certain amount of emissions per unit of output) without mandating particular technologies.

\section{Intrinsic cost-effectiveness}

31. By forcing all firms to undertake specific emission reduction efforts regardless of their individual abatement costs, CAC instruments do not, in general, achieve marginal abatement cost equalisation and, thus, do not minimise overall abatement costs (see e.g. Bohm and Russell, 1985). Also, technology standards are usually more costly than performance standards, as the latter give firms greater flexibility in selecting the abatement option that is most adapted to their individual situation. ${ }^{34}$ For a CAC instrument to be as cost-effective as a market-based incentive, firms' marginal abatement costs should be similar, or the regulator should have full information about individual cost structures and set regulation accordingly. These conditions are unlikely to be met in practice. Also, standards can be subject to "regulatory capture" by lobbies that gradually undermines economic efficiency, e.g. through the establishment of de facto entry barriers in regulated industries. Finally, unlike price-based instruments, standards do not yield any "double dividend" since they do not raise fiscal revenues. ${ }^{35}$

32. However, if carefully designed, CAC instruments can contribute to deal with a number of market imperfections that are left unaddressed by market-based incentives:

- When emissions cannot be perfectly observed (e.g. fugitive emissions from pipelines, methane from agriculture), market-based incentives no longer minimise abatement costs as they do not address the monitoring issue. In principle, cost-effectiveness can then be enhanced through the use of technology standards - performance standards are useless in this context since their implementation also requires adequate emissions monitoring. When the emissions observation imperfection is large and abatement costs are relatively homogenous across agents, such standards have been shown to be more cost-effective than market-based incentives (Montero,

34 One exception is when emissions are difficult and/or costly to monitor, in which case performance standards are ineffective and technology standards provide a better option (see below).

However, when fiscal revenues from price-based instruments are recycled to affected industries, the relative performance of standards improves, and might even turn into an absolute advantage under extreme conditions where industry-compensation requirements are high and distorsive, and producers' abatement costs are homogenous and known by the regulator (Bovenberg et al. 2008). 
2005). Their performance can be further enhanced by combining them with market incentives whose effects can be measured, when these are available. ${ }^{36}$

- In situations where asymmetric information between two contracting parties with opposite goals creates adverse selection and/or moral hazard problems, well-designed CAC instruments may also perform better than market incentives. Examples of such market failures have been identified especially in energy service markets (Sorrell et al. 2000, IEA, 2007). For instance, in the housing market, landlords have better information than tenants but have little incentive to install the most energy-efficient equipments as they do not pay the energy bill. Likewise, asymmetric information between buyers and sellers may also prevent house prices from fully reflecting the discounted value of efficiency investments. The invisibility of energy-efficiency performance of electrical appliances and light bulbs may also prevent households from optimising energy consumption. In such cases, policy should as much as possible address directly the market failure involved through information instruments, such as public disclosure requirements or eco-labelling. However, when information instruments are costly or insufficient, standards can be justified, and they have been found to yield sizeable welfare gains. ${ }^{37}$

- It has also been argued that CAC instruments should be preferred to market-based incentives in situations where agents are little responsive to price signals. For instance, lack of institutional including monitoring - capability may impede the proper functioning of market-based incentives in lower-income countries, while technology standards may be comparatively easier to implement and track (Blackman and Harrington, 2000; Russell and Vaughan, 2003). As well, standards may help raise emissions abatement in state enterprises with market power closer to levels that would be undertaken if such firms operated under private governance in competitive markets (Sterner, 2003).

33. The theoretical case for CAC instruments should, however, be qualified on three grounds:

- Policymakers should make sure that the use of standards addresses genuine market failures, rather than merely high transaction costs. Hidden transaction costs may explain why apparently efficient investment decisions - e.g. in energy efficient equipments - are rationally not taken up by optimising households and firms. For example, transaction costs, rather than market imperfections, may partly explain why landlords and tenants do not in practice sign the type of shared-savings contracts that would seem to benefit both parties a priori. More broadly, economists have often been sceptical with respect to the existence of profitable ("negative cost") abatement opportunities. ${ }^{38}$ Insofar as such apparent opportunities reflect hidden transaction costs rather than market failures, it becomes less clear that standards would yield net social benefits, and in any event direct policies to reduce transaction costs would be more effective.

For instance, in a study of local car pollution, Fullerton and West (2000) find that in the presence of imperfect emissions monitoring and large abatement cost heterogeneity across producers, over two-thirds of the potential welfare gain not captured by standards can still be recovered by complementing them with a set of taxes and subsidies based on vehicle age and size.

For instance, Levine et al. (1994) and Eto et al. (1994) find large net private benefits (without even factoring in the environmental gains) from US appliance standards and US lighting programmes, respectively.

For instance, Enkvist (2007) argues that a significant amount of GHG emissions abatement at the world level could be undertaken at a net financial benefit. For some theoretical support for the view that regulation can help (non-optimising) firms reap costless pollution abatement opportunities, see Porter and van der Linde (1995). For a sceptical economist view, see Palmer et al. (1995). 
- Some of the market failures and/or transaction costs that are put forward to justify the use of CAC instruments may in fact not be fully independent from the existence (or lack of) of a carbon price. As regards information asymmetry for example, the higher the price of GHG emissions and the energy bills, the stronger the incentives for tenants and buyers to find information about the energy efficiency of alternative equipments, and for landlords and sellers to reveal this information. A similar argument could be made with respect to contract incompleteness. For instance, consumers currently have little or no choice regarding the energy efficiency of the services provided with television set-top boxes (IEA, 2007). With a high-enough carbon price, there would be greater incentives for buyers and sellers to have two separate transactions for the television set-top boxes and the services.

- Finally, a theoretical case for policy intervention should be weighed against the risk of policy failure. There are two main risks of policy failure: $i$ ) as just noted, the magnitude of the market imperfection(s) to be addressed is hard to pin down in practice; ii) in the absence of detailed information about individual abatement costs, it is challenging for the regulator to determine the appropriate degree of stringency of the standard. This underlines the need for undertaking serious cost-benefit analysis before setting up standards.

\section{Adoption and compliance incentives}

34. CAC instruments have a number of political features that encourage their adoption. They already represent the most common form of environmental regulation, can be easily enforced through existing national institutions, and unlike price instruments their costs are not immediately visible to voters. It has also been argued that international negotiations to set technology standards for key emitting industries could succeed in bringing large emitters from developing countries on board, if accompanied by technology transfers (Barrett, 2007).

35. However, CAC instruments offer little scope for addressing the "free-rider" problem affecting international climate policy negotiations. As a result, if large reductions in worldwide GHGs were to be secured through standards, adoption incentives could be weak. Unlike with permits, burden-sharing rules cannot be built in CAC instruments and would, therefore, have to be negotiated separately. Information problems would affect such negotiations, reflecting the difficulty to assess the costs of implementing standards. Finally, it is unclear whether international standards would actually be desirable. While expanding the international coverage of price instruments always reduces the overall cost of achieving a given worldwide reduction in GHG emissions, mandating uniform standards across all countries may not.

\section{$R \& D$ and technology diffusion incentives}

36. Unlike price instruments, standards do not give emitters continuing incentives to exploit cheap abatement options beyond what is needed to comply, thereby resulting in lower innovation and adoption incentives (see Jaffe et al. 2003; Downing and White, 1986; Jung et al. 1996; Keohane, 2001; Milliman and Prince, 1989; Zerbe, 1970). ${ }^{39}$ Under technology standards, firms have no incentive to develop

For empirical evidence that permit trading yields larger technology adoption incentives than binding performance standards (based on historical experiences in the United States with the phase down in lead in gasoline and the reduction in sulphur dioxide emissions, respectively), see Kerr and Newel (2004) and Keohane (2001). In theory, the greater strength of innovation incentives under market-based instruments may not always hold under oligopolistic competition. Montero (2002) finds that a stringent emissions standard may have a larger innovation impact than a tradable permit scheme under quantity-based (Cournot) competition (but not under price-based (Bertrand) competition). This is because firms spontaneously under-invest in R\&D under quantity-based competition, since the change in rival firms' output as a result of R\&D spillovers would reduce the innovating firm's profits, ceteris paribus. 


\section{$\mathrm{ECO} / \mathrm{WKP}(2008) 44$}

alternative, potentially more effective technologies than those mandated by regulation. From this perspective, innovation incentives are stronger under performance standards, but are limited by the fact that emitters do not gain from reducing emissions below levels requested to comply with regulation. Research in regulated firms may also be discouraged by a perceived risk of "regulatory ratchet", whereby standards would be further tightened a posteriori if a new technology were found (see e.g. Hahn and Stavins, 1991). ${ }^{40}$ More broadly, uncertainty about future regulation and, therefore, about the future (implicit or "shadow") price of emissions undermines research incentives. Finally, while ambitious technology and performance standards can in principle be set to "force" innovation, ${ }^{41}$ it is difficult for the regulator to determine the appropriate stance a priori, with the risk that innovation incentives will be either too weak or too strong.

\section{Ability to cope effectively with risk and uncertainty}

37. CAC instruments are not well suited to cope with the uncertainty surrounding both the damages from climate change and the costs of reducing GHG emissions. They provide certainty neither about GHG emissions nor about abatement costs. Furthermore, they accommodate change - whether of emission targets, economic conditions or abatement technologies - less easily than price instruments. For instance, under taxes or tradable permits, individual emitters' response to new technologies is spontaneous and decentralised. By contrast, under a CAC approach, firms have little control over facility-specific abatement decisions, and the regulator must re-specify all the standards affecting the many different types of emitters.

\subsection{Technology-support policies}

38. Technology-support policies include instruments that provide R\&D and/or technology adoption incentives. On the R\&D side, they range from basic public research to direct government funding of private $\mathrm{R} \& \mathrm{D}$ and tax incentives, and may also be seen as including the strengthening of IPRs. On the technology adoption side, they may include inter alia subsidies, legal obligations (e.g. for electricity providers to purchase a certain share of their electricity from renewable sources, which may be best achieved through market mechanisms such as "green certificates") and public purchases. In the case of a global problem like climate change, the issue arises of whether and how such incentives should be coordinated across countries. International co-ordination sends consistent signals to investors worldwide, spreads risks and avoids duplication, but it involves higher transaction costs. The purpose of this section is to discuss the rationale for using technology-support policies to address climate change, rather than to discuss the pros and cons of each possible instrument or institutional arrangement. ${ }^{42}$

\section{Intrinsic cost-effectiveness}

39. R\&D and/or technology adoption instruments alone do not provide a cost-effective way of achieving a given GHG emissions reduction objective, for three main reasons (see in particular Fischer and Newell, 2007; Schneider and Goulder, 1997):

$40 \quad$ A parallel could be made here with so-called "RPI-X" price cap regulation of monopolies. RPI-X regulation aims to mimic the incentives for cost efficiency found in competitive markets by setting a predetermined price cap. In principle, this provides strong incentives for monopolistic firms to cut costs in order to increase profitability. In practice, however, RPI-X regulation runs a risk of time-inconsistency, since the regulator has an incentive to revise the price cap downwards a posteriori, should cost reductions and the associated monopoly rents turn out to be higher than expected.

41 However, as discussed in Jaffe et al. (2003), available empirical evidence about such forced innovation remains ambiguous.

42 For some recent OECD comparative analysis of R\&D incentives and empirical evidence regarding their effects on R\&D and innovation, see Jaumotte and Pain (2005) and Guellec and van Pottelsberghe (2004). 
- Most importantly, unlike taxes or permits, they do not directly address the negative externality from GHG emissions. As a result, they do not change demand patterns. For instance, they do not provide incentives to reduce energy intensity (through an increase in energy prices) or to reduce the emissions intensity of fossil fuels (e.g. by shifting from coal-fired to gas-fired power plants).

- To the extent that these policies take the form of subsidies, they need to be financed, thereby creating distortions in the economy. Such distortions matter all the more as large R\&D and/or technology adoption incentives may be required to offset the absence of a carbon price, for a given emissions reduction objective (Fischer and Newell, 2007).

- Finally, in the specific case of R\&D policies, cost-effective early abatement opportunities are foregone, and all emission reductions must be achieved at a later stage by making new technologies less expensive than "carbon-intensive" technologies, in the absence of carbon pricing. This may require very large initial R\&D spending. ${ }^{43}$

\section{Adoption and compliance incentives}

40. Technology-support policies have a number of attractive political features:

- The perceived trade-off between economic growth and mitigation policies is lower with such policies, for two main reasons. First, insofar as they help address innovation failures, they may actually boost economic growth. ${ }^{4}$ Second, they postpone actual emission cuts until new technologies become available in the future. As a result, they are usually seen as less costly to the current generation than other available options. Certain R\&D policies can even be "no cost" in the short run, such as advanced commitments (see below).

- From a standard political economy perspective, their costs are usually spread widely across the population, while their benefits are more concentrated on potential innovators. This increases the likelihood that they are adopted.

- They provide one possible burden-sharing mechanism, and as such may be used to facilitate wide adoption of a post-2012 agreement. For instance, it has been suggested that developed countries could finance most of the research and commit to subsidising technology transfers to developing countries when the new technologies become available, e.g. by buying out IPRs and transferring them at below-market price.

\section{$R \& D$ and technology diffusion incentives}

41. R\&D policies and technology adoption incentives are better suited than price and CAC instruments to address specific innovation and technology diffusion failures that undermine the creation and diffusion of emissions-reducing technologies. The case for R\&D support seems most convincing in the case of major innovations, whose rents are most difficult to capture, not least because strong protection of IPRs may not be fully credible. However, in order to be effective, R\&D policies should as much as possible target specifically emissions-reducing technologies. For instance, R\&D in the area of energy

$43 \quad$ For this reason, based on a calibration of their theoretical model to US electricity sector, Fischer and Newell (2007) find R\&D subsidies to be the costliest policy option to reduce emissions from electricity production, followed by renewable energy adoption incentives, emissions performance standards and emissions pricing. 
efficiency may be less effective than R\&D focused on reducing the carbon intensity of energy. This is because improvements in energy efficiency have a direct negative impact on the demand for fossil fuels but an indirect positive effect via the associated fall in prices.

42. The case for technology-adoption incentives, e.g. in the form of subsidies to renewable energy or biofuels, can be justified by the presence of learning-by-doing and/or using effects. However, the potential benefits from policy intervention need to be weighed against its economic and - especially as regards biofuels - environmental costs. As well, public support to technology diffusion can be a double-edged sword, insofar as poor policy choices and lobbying by interest groups run the risk of "locking-in" the wrong technologies, in the presence of increasing returns to adoption. ${ }^{45}$

43. As already mentioned, in the absence of any price to GHG emissions, technology-support policies do not provide a cost-effective way to stimulate innovation and technology diffusion (Fischer and Newell, 2007). ${ }^{46}$ They are, therefore, most effective as a complement to carbon pricing. However, technology-support policies are also potentially time-inconsistent. In answer to this concern, it has been suggested that a contract through which a global fund would commit in advance to reward any major innovation would be legally enforceable and, therefore, credible. However, given that firms are likely to be better informed than governments about costs and potential returns from $\mathrm{R} \& \mathrm{D}$, setting the appropriate level of the reward - i.e. one that encourages innovation today without providing excessive rents to future innovators - would be challenging. ${ }^{47}$

\section{Ability to cope effectively with risk and uncertainty}

44. Technology-support policies provide no certainty regarding environmental outcomes, even in the long run. This reflects the uncertainty surrounding both the lags needed for R\&D to pay off and its social return. As a result of this lack of responsiveness, technology-support policies would be vulnerable to worse-than-expected climate trends. Neither do such policies provide certainty about abatement costs in the long run, if used alone to achieve a given emissions reduction target.

\subsection{Voluntary agreements}

45. Voluntary agreements (VAs) between governments and one or more private parties to limit GHG emissions have also been put forward as one possible climate mitigation instrument. VAs have long been used in a number of environmental areas in some OECD countries and they have received growing attention within the context of climate change in recent years. By contributing to information gathering and diffusion of best-practice, they can help address information problems in a way that is similar to information instruments. Furthermore, they raise awareness and understanding of mitigating options at the firm and industry level, rely on consensus building and are easy to implement, all of which facilitates their adoption compared with more stringent instruments. By affecting the willingness of firms to take concrete

$45 \quad$ See the discussion in Jaffe et al. (2003).

46 However, two empirical studies by Jaffe and Stavins (1995) and Hassett and Metcalf (1995) find larger effects from technology cost subsidies than from energy taxes on energy efficiency improvements in US households/residences. Possible explanations for these findings include uncertainty over the future price of energy and capital market failures (Jaffe et al. 2003)

See Kremer (2001b) for some discussion in the case of markets for vaccines. The author suggests that the reward offered by the global fund could start relatively low and then pick up gradually if the pace of innovation is deemed insufficient. This process would mimic an auction, which often offers an efficient procurement method when costs are unknown. However, such an iterative procedure may be difficult to apply to climate mitigation technologies, because the lag between policy decision and a perceptible impact on innovation is likely to be long (e.g. in the area of electricity production). 
steps towards reducing emissions, VAs may also pave the way for the adoption of more stringent policies at a later stage, although they also run the risk of regulatory capture.

46. However, implementation is key to reaping these potential benefits. Indeed, VAs can vary widely in terms of stringency, monitoring and enforcement. Agreements that are likely to be most effective include measurable emission targets below a well-defined baseline scenario, monitoring and reporting requirements by an independent party, and compliances incentives such as penalties (Hanks, 2002; OECD, 2003). In any event, the impact of VAs on emissions and their cost-effectiveness are hard to assess, given potential selection bias (e.g. more energy-efficient firms have larger incentives to enter into VAs) and the difficulty to determine the counterfactual (i.e. emission trends in the absence of the VA).

47. VAs should best be seen as domestic complements to national or international policy frameworks including more cost-effective policies, not least price instruments. Indeed, considered alone, VAs do not meet the main criteria against which to assess the overall cost-effectiveness of alternative policies, namely:

- They are not intrinsically cost-effective. There is no reason a priori to expect any effects on emissions to be achieved by exploiting the cheapest abatement opportunities - if only because of partial coverage.

- They do not provide appropriate innovation incentives on a broad scale, although they may facilitate the diffusion of existing emissions-reducing technologies within the industries covered. At best, they are likely to face the same limits as standards, i.e. emitters do not have continuing incentives to find cheap abatement options beyond what is agreed within the context of the VA.

- Finally, they cannot cope effectively with risk and uncertainty. They provide certainty neither about GHG emissions nor about abatement costs, and unlike price instruments they do not accommodate change spontaneously.

\section{Interactions across policy instruments}

48. The wide range of available GHG emissions-reducing policies and possible interactions among them raises the issue of whether and how they can be integrated into a coherent framework. While multiple market failures arguably call for multiple policy instruments, there are also risks of poorly-designed policy mixes resulting in undesirable overlaps, which would undermine cost-effectiveness and, in some cases, environmental integrity. There are basically three main possible types of interaction among policy instruments (Sorrell, 2002; Sorrell and Sijm, 2003):

- A direct interaction arises when the target groups directly affected by two policies overlap in some way. For example, some or all of the participants in a permit-trading scheme may at the same time be subject to a carbon or fuel tax.

- An indirect interaction occurs when a target group that is directly - or sometimes indirectly affected by one policy is also indirectly affected by another policy. For example, there is an indirect interaction between a downstream permit-trading scheme that includes the electricity generators and an electricity tax on consumers. This is because consumers are directly affected by the electricity tax and indirectly affected - through higher electricity prices - by the emissions trading scheme. Likewise, there is an indirect interaction between a downstream permit-trading scheme and any obligation upon electricity suppliers to purchase - possibly in the form of tradable credits - renewable electricity, as both ultimately lead to higher consumer prices. 
- A trading interaction denotes a situation where two policies interact with one another through the exchange of an environmental trading commodity, such as a GHG emissions allowance. For instance, allowances from one permit-trading system may be exchangeable for allowances from another scheme, under specific rules defining the fungibility of both commodities. The Clean Development Mechanism (CDM) of the Kyoto Protocol, or any linking between two different permit-trading schemes, offers prime examples in this regard. Likewise, there may be trading interactions between GHG emission permits and tradable credits for renewable electricity, if allowances from the latter can be used for compliance with the former. Trading interaction may be seen as a special case of indirect interaction, where the target group directly affected by one scheme is indirectly affected by the other through allowances trading.

49. Whether any of these interactions is desirable on the grounds of cost-effectiveness - and, in some cases, environmental integrity -depends on two main factors, namely whether the instruments considered address different market imperfections and/or affect different target groups (see e.g. OECD, 2007b). When this is the case, they are complementary and may be combined so as to enhance cost-effectiveness, compared with a situation where only one single instrument is used. Otherwise, instruments overlap and overall mitigation costs increase for two main reasons: $i$ ) double regulation usually entails some loss of flexibility on the part of firms in picking-up least-cost abatement options; and, ii) administrative costs are unnecessarily increased. The rest of this section highlights a number of important examples of policy complementarities and overlaps that are likely to be encountered in practice.

\section{1. $\quad$ Policy complementarities}

\section{Complementarities across climate policy instruments}

50. As the previous section has shown, none of the instruments commonly available to policymakers can simultaneously address the multiple market imperfections involved in achieving cost-effective GHG emission reductions. Therefore, overall mitigation costs may be lowered by combining policy instruments according to their comparative advantage in addressing each market imperfection. ${ }^{48}$ Concretely, in light of the previous discussion, there may be a case for:

- Addressing the environmental externality generated by GHG emissions by putting a price on GHG emissions, either through taxes or permit trading.

- Addressing those innovation and diffusion failures that are specific to emissions-reducing technologies through R\&D and technology adoption instruments, respectively, over and above setting policies that deal with general innovation and diffusion failures.

- Overcoming information failures (asymmetric information, imperfect monitoring) through information and CAC instruments.

51. Furthermore, carbon pricing is unlikely to cover all world emission sources in practice, at least over the medium run. This leaves a number of cheap abatement opportunities unexploited and further widens the gap between social and private returns from emissions-reducing technologies. Against this

48 In particular, there is burgeoning theoretical and empirical evidence that a policy package combining carbon pricing and technology-support policies could significantly reduce mitigation costs. For instance, based on a theoretical model calibrated on US electricity sector data, Fischer and Newell (2007) suggest that optimal R\&D and renewable subsidies could lower by over a third the $\mathrm{CO}_{2}$ emissions price needed to achieve a 5\% cut in US electricity sector emissions, and could bring down the overall cost of the policy package to zero, due to the positive spillovers generated by the technology-support policies. 
background, there may be a "second-best" argument for using CAC instruments and technology-support policies to curb unpriced emissions and boost innovation and technology adoption incentives, respectively:

- In order to justify the use of CAC instruments in this context, not only should their target groups differ from those covered by taxes or permits, but their implicit (shadow) price should not exceed the carbon price. As well, their use should not lead to the establishment of vested interests that would oppose the adoption of price instruments at a later stage.

- As regards technology-support policies, one open question is an international permit trading system could give credit (through permit allocation rules) to participants for their R\&D investments. This might increase both participation and R\&D incentives, thereby contributing to deal with the public good nature of both climate and innovation. However, this would need to be done in a way that does not undermine the environmental integrity of the permit scheme, and does not give excessive rewards to R\&D efforts, given that carbon pricing would already in and by itself provide some R\&D incentives.

\section{Complementarities between climate mitigation instruments and policies in other areas}

52. The overall cost-effectiveness of a climate policy package can also be enhanced by reforming a number of policies that either increase GHG emissions or distort the incentives - and, therefore, raise the cost - of mitigation instruments, including:

- Energy policies: Fuel tax rebates and energy price regulations are still being used as social policy devices in many developing and middle-income countries, including China, India, Russia, and parts of Eastern Europe. They amount to subsidising reductions in energy efficiency, and thereby distort the incentive effects of mitigation instruments and resource allocation throughout the economy more broadly. As well, energy markets -electricity production and distribution in particular - remain highly regulated in many countries. Greater competition would increase the welfare gains from emission taxes or permit trading schemes.

- Trade policies: Tariff and non-tariff barriers to imports of emission-reducing goods and services unnecessarily hamper the effectiveness of abatement policies. Reflecting such barriers, only about $10 \%$ of the world's ethanol consumption is currently met through international trade (Walter et al. 2007), even though biofuels produced in tropical regions from sugarcane and palm oil have a considerable comparative advantage over those derived from agricultural crops in temperate zones, owing both to their intensity in cheaper labour and much higher physical yields (Girard and Fallot, 2006). Existing barriers to imports of energy-efficient electrical appliances and renewable-energy products and technologies offer other examples of trade protection hampering the cost-effectiveness of mitigation policy and/or leading to increased emissions. In this area, there seems to be room both for lower tariffs in many non-OECD countries and for lower non-tariff barriers - at least via greater harmonization of criteria and tests for energyefficiency requirements - in their OECD counterparts.

- Agricultural policies: Agricultural support in developed countries - not least in the European Union (EU), the United States (US) and Japan - distorts relative prices and may also undermine the cost-effectiveness of mitigation policies. Their impact on world GHG emissions is less straightforward and is mainly an empirical matter. On the one hand, they raise emissions directly through higher agricultural output (e.g. methane emissions from rice and livestock), and indirectly through overuse of pesticides and fertilisers. On the other hand, their removal would induce a shift in agricultural output towards more carbon-intensive producers from developing 
countries, and would trigger some reallocation of resources towards non-agricultural industries that may not necessarily emit less.

- Legal frameworks: Lack of legal frameworks and effective (enforcement of) property rights encourages widespread deforestation in some parts of South America, South-East Asia and Africa. Unsustainable land use practices are even more widespread, including OECD countries as well as developing regions. Establishing stronger legal frameworks for land use management, emissions monitoring and property rights, along with specific burden-sharing arrangements, may be needed to stimulate (possibly) cheap emission reductions in this area.

\subsection{Policy overlaps}

53. Policies overlap if they address similar market failures and affect directly or indirectly the same target groups. Two prominent illustrations of such double regulation are the following:

- Similar emission sources are directly or indirectly covered by both tradable permits and a carbon tax. Under a permit-trading system, overall emissions are set by the cap. In this context, by increasing emitters' abatement efforts, a carbon tax frees up emission permits and puts downward pressure on their price (see e.g. OECD, 2007a, 2007b). Ultimately, the carbon tax is fully offset by a fall in the permit price, leaving unchanged total emissions but unduly raising administrative costs. A carbon tax is, therefore, redundant, unless it is set at a level high enough to bring the permit price down to zero, in which case it is the permit-trading system that becomes redundant. Furthermore, if the target groups of both instruments overlap partly rather than fully, different emitters face different incentives to cut emissions, thereby raising mitigation costs. This is because emissions are then priced once, twice or unpriced depending on whether emitters are covered by one instrument, both or none. As a result, some emitters end up abating too much and others too little compared with the (marginal) cost of doing so. ${ }^{49}$

- Likewise, similar emission sources may be covered both by an economy-wide (national or international) tradable permit system and by an international cap-and-trade scheme at the sectoral level (i.e. a binding sectoral agreement). This is another example where the target groups of two instruments partly overlap, with emissions being priced once or twice depending on whether emitters are covered by one or both schemes. In such cases, permit fungibility between schemes, along with double crediting of emission reductions for those emitters that are covered twice, would ensure that all emitters face similar emission prices, thereby ensuring economic efficiency.

54. A similar source of policy overlap arises if carbon pricing - be it through taxes or permits - is supplemented with other instruments to address only the environmental externality generated by GHG emissions. Such instruments may include for instance transport fuel taxes, energy efficiency standards, or obligations upon electricity suppliers to purchase particular electricity sources (e.g. renewable energy ("green") certificates), etc. Under permit-trading, any of these additional policies puts downward pressure on the permit price and leaves unchanged overall emissions, unless the policy is so stringent that the permit price falls down to zero. Under a carbon tax, the additional policy reduces overall emissions, but raising the carbon tax rate would achieve the same result at a lower cost. The bottom line is that in the presence of a carbon price, there is little or no role for other policies in addressing the GHG emissions externality. For instance, keeping a transport fuel tax can be justified only as way to raise general tax revenues and/or only

49 For instance, the co-existence of comprehensive carbon taxation with the participation of electricity generators in a permit-trading system distorts the incentives to substitute between electricity (covered twice) and other emission sources (covered once). 
to the extent that it addresses other externalities such as congestion and local pollution. Likewise, renewable energy obligations should reflect adoption spillovers and/or energy security considerations.

55. Trading interactions across different schemes also need to be taken into account in order to avoid overlaps and preserve overall environmental integrity. For instance, if a firm is covered by two different permit-trading schemes, there can be a risk of counting the same emissions or the same emission reductions twice, two issues called respectively "double coverage" and "double crediting" (Sorrell and Sijm, 2003). While double coverage is usually offset by double crediting, in which case the environmental integrity of either scheme is not threatened, this needs not always be the case. For example, if firms covered by a tradable permit system can earn credits through particular energy-efficiency improvements or renewable energy projects they could have undertaken anyway to meet their emission commitments, there will be double crediting without any compensating double coverage, and the emissions cap will be breached.

\section{Main findings}

56. The main findings from this paper are as follows:

- A cost-effective international policy framework to reduce GHG emissions should minimise the overall economic cost of achieving any given climate mitigation objective. To this end, alternative policy options may be assessed along three broad criteria: $i$ ) the extent to which they abate existing emissions at least cost, which in turn requires the set of instruments to be not only cost-effective per se but also to provide sufficient political incentives for wide adoption and compliance; ii) whether they foster an efficient level of innovation and diffusion of GHG emissions-reducing technologies; and, iii) their ability to cope effectively with uncertainty surrounding both climate change and abatement costs.

- Multiple market imperfections need to be addressed in order to meet these three criteria. Abating world emissions at least cost is hampered by the global public good nature of climate and the associated "free-riding" incentives, as well as by information problems for certain emission sources. Innovation and diffusion of clean technologies is undermined by knowledge and adoption spillovers, which drive a wedge between the expected social and private returns from $\mathrm{R} \& \mathrm{D}$ and adoption. This wedge may be further increased by the political uncertainty about future climate policy, as well as by the insufficient credibility of intellectual property rights on pathbreaking innovations. Finally, coping effectively with uncertainty is mainly hindered by the nonnegligible but yet largely unknown probability of large and irreversible consequences of climate change, in a context where there are long lags between policy action and its effect on the climate.

- Putting a price on GHG emissions through price mechanisms (taxes, tradable permits or a hybrid system combining features of both) can go a long way towards building up a cost-effective climate policy framework. Although taxes and tradable permits differ in a number of respects, both are intrinsically cost-effective, give emitters continuing incentives to search for cheaper abatement options through both existing and new technologies, and can be designed and adjusted to minimise short-run uncertainty about emission abatement costs - e.g. through the use of banking and borrowing provisions and price caps in the case of permits - and longer-run uncertainty about environmental outcomes.

- One limitation of price instruments is that they do not address the full range of market imperfections that prevent emissions to be cut at least cost, such as information problems. These may arise for instance when emissions are difficult and/or costly to monitor, or when some agents have incomplete information about emissions and abatement options. In such cases, information 
instruments (e.g. public disclosure requirements or eco-labelling), voluntary agreements and/or standards (e.g. building codes, household electric appliance standards) at the domestic level can complement price instruments. Nevertheless, if used they should address genuine market failures rather than merely high transaction costs. As well, given the difficulty to determine the appropriate degree of stringency of the standard, the case for such policy intervention should be weighed against the risk of policy failure.

- Price instruments alone are also unlikely to deliver adequate investment in innovation and diffusion of emissions-reducing technologies, reflecting the existence of knowledge and adoption spillovers. Such market imperfections exist in other research areas, but they may be particularly large in the case of climate change mitigation. This is due inter alia to the political uncertainty surrounding future climate policy, as well as to the potential lack of credibility of IPRs to private investors. R\&D and technology adoption policies are therefore called for, especially to encourage major innovations, whose rents are most difficult to capture (e.g. general-purpose technologies in the area of electricity production). As well, one possible answer to uncertainty and credibility problems would be to set up a global fund that would commit in advance to reward any major innovation.

- Another important limitation of price instruments is the difficulty to design them in a way that overcomes income distribution, competitiveness and other political economy obstacles to adoption and compliance both across and within countries. Permit trading may be less vulnerable than a tax in this regard, because it allows more flexible, more credible and more discrete burdensharing agreements, builds up a clear constituency (permit holders) with an interest in enforcing the policy in the future, and enables some degree of sovereignty to be maintained in implementation at the country level. Technology transfers, e.g. through buying out patent rights on clean technologies before subsidising their transfer to developing countries, may also contribute to burden-sharing.

- In principle, other options exist to raise participation incentives and address competitiveness concerns, such as countervailing tariffs on carbon-intensive imports from non-participating countries, or government-led international sectoral agreements covering the main multinational firms in a few key energy-intensive industries. However, the non-co-operative nature of the former entails trade retaliation risks. Furthermore, both approaches can be costly, especially if poorly designed, and they do little to address the carbon leakage that occurs through the fall in world fossil fuel prices. Therefore, priority may be given primarily to enhancing country participation incentives primarily through burden sharing agreements, possibly along with complementary sectoral approaches where needed.

- The cost-effectiveness of global emission cuts can be further enhanced by reforming a number of policies that either increase GHG emissions or distort the incentives - and, therefore, raise the cost - of mitigation instruments. These include inter alia fuel tax rebates, energy price regulations and lack of property rights on forest in a number of developing countries, as well as import barriers to emissions-reducing technologies and agricultural support in a number of developed countries.

- In order to achieve a cost-minimising policy package that exploits complementarities between different instruments, these need to address different market imperfections and/or affect different target groups. If this is not the case, there will be some policy overlap, and double regulation will raise mitigation costs. One illustration is when an emissions source that is already (directly or indirectly) covered by tradable permits is also subject to a carbon tax, a transport fuel tax, an energy efficiency standard, or some obligations upon electricity suppliers to purchase particular 
electricity sources. In the presence of permit trading, such policies raise costs without further cutting emissions. Apart from the need to raise general tax revenues, they must then be justified on other grounds, such as congestion and local pollution in the case of a transport fuel tax, or adoption spillovers and energy security in the case of renewable energy obligations. 


\section{BIBLIOGRAPHY}

Barret, S. (2007), "Proposal for a New Climate Change Treaty System", The Economists' Voice, Vol. 4, No. 3.

Baron, R. and J. Ellis (2006), "Sectoral Crediting Mechanisms for Greenhouse Gas Mitigation: Institutional and Operational Issues", OECD, COM/ENV/EPOC/IEA/SLT(2006)4.

Biglaiser, G., J. Horowitz and J. Quiggin (1995), "Dynamic Pollution Regulation", Journal of Regulatory Economics, Vol. 8, No. 1.

Blackman, A. and W. Harrington (2000), "The Use of Economic Incentives in Developing Countries: Lessons from International Experience with Industrial Air Pollution", Journal of Environment and Development, Vol. 9, No. 1.

Bohm, P. and C. Russell (1985), "Comparative Analysis of Alternative Policy Instruments", in A. Kneese and J. Sweeney (eds.), Handbook of Natural Resource and Energy Economics, Vol. 1, North Holland, Amsterdam.

Bovenberg A., L. Goulder and M. Jacobsen (2008), "Costs of Alternative Environmental Policy Instruments in the Presence of Industry Compensation Requirements", Journal of Public Economics, Vol. 92, No. 5.

Buchanan, J. (1969), "External Diseconomies, Corrective Taxes, and Market Structure", American Economic Review, Vol. 59, No. 1.

Burtraw, D., D. Kahn and K. Palmer (2006), "Dynamic Adjustment to Incentive Based Policy to Improve Efficiency and Performance", mimeo, Resources for the Future, Washington D.C.

Capoor, K. and P. Ambrosi (2006), State and Trends of the Carbon Market 2006, IETA and World Bank, Washington D.C.

Congressional Budget Office (2008), Policy Options for Reducing CO2 Emissions, Washington D.C.

Cropper, M. and W. Oates (1992), "Environmental Economics: A Survey", Journal of Economic Literature, Vol. 30, No. 2.

De Mooij, R. (1999), “The Double Dividend of Environmental Tax Reform”, in J.C. van der Bergh (ed.), Handbook of Environmental and Resource Economics, Cheltenham, Edward Elgar, U.K.

Denicolo, V. (1999), "Pollution-reducing innovations under taxes or permits", Oxford Economic Papers, Vol. 51, No. 1.

Dixit, A. and S. Pindyck (1994), Investment Under Uncertainty, Princeton University Press, Princeton, N.J. 
Downing, P. and L. White (1986), "Innovation in Pollution Control", Journal of Environmental Economics and Management, Vol. 13, No. 1.

Dudek, D. and A. Golub (2003), “'Intensity Targets': Pathway or Roadblock to Preventing Climate Change While Enhancing Economic growth?," in M. Marcu and W. Pizer (eds.) (2003), "Special Supplement on Defining and Trading Emission Targets", Climate Policy, Vol. 3, Supplement 2.

Ellis, J. and R. Baron (2005), "Sectoral Crediting Mechanisms: An Initial Assessment of Electricity and Aluminium", OECD, COM/ENV/EPOC/IEA/SLT(2005)8.

Ellis, J. and D. Tirpak (2006), "Linking GHG Emission Trading Systems and Markets", OECD, COM/ENV/EPOC/IEA/SLT(2006)6.

Enqvist, P-A. (2007), “A Cost Curve for Greenhouse Gas Reduction”, McKinsey Quarterly, No. 1.

Eto, J., E. Vine, L. Shown, R. Sonnenblick and C. Payne (1994), The Cost and Performance of Utility Commercial Lighting Programmes, Lawrence Berkeley Laboratories, Berkeley, CA.

Fischer, C., I. Parry and W. Pizer (2003), "Instrument Choice for Environmental Protection when Technological Innovation is Endogenous", Journal of Environmental Economics and Management, Vol. 45, No. 3.

Fischer, C. and R. Newell (2007), "Environmental and Technology Policies for Climate Mitigation", Journal of Environmental Economics and Management, Vol. 55, No. 2.

Frankel, J. (2007), "Formulas for Quantitative Emissions Targets", in J. Aldy and R. Stavins (eds), Architectures for Agreement: Addressing Global Climate Change in the Post-Kyoto World, Cambridge University Press, Cambridge.

Fullerton, D. and S. West (2000), "Tax and Subsidy Combinations for the Control of Car Pollution", NBER Working Paper No. 7774.

Girard, P. and A. Fallot (2006), "Review of Existing and Emerging Technologies for the Production of Biofuels in Developing Countries", Energy for Sustainable Development, Vol. 10, No. 2.

Goulder, L. (1995), “Environmental Taxation and the Double Dividend: A Reader's Guide", International Tax and Public Finance, Vol. 2, No. 2.

Goulder, L., I. Parry, R. Williams and D. Burtraw (1999), "The Cost-effectiveness of Alternative Instruments for Environmental Effectiveness in a Second-Best Setting", Journal of Public Economics, Vol. 72, No. 3.

Goulder, L. and S. Schneider (1999), "Induced Technological Change and the Attractiveness of CO2 Abatement Policies", Resource and Energy Economics, Vol. 21, Nos. 3-4.

Guellec, D. and B. van Pottelsberghe (2004), "From R\&D to Productivity Growth: Do the Institutional Settings and the Source of Funds of R\&D Matter?", Oxford Bulletin of Economics and Statistics, Vol. 66, No. 3.

Gupta, S., D. Tirpak, N. Burger, J. Gupta, N. Höhne, C. Kolstad, J. Kruger, A. Michaelowa, S. Murase, J. Pershing, T. Saijo, and A. Sari (2007), "Policies, Instruments and Co-operative arrangements", in B. Metz, O. Davidson, P. Bosch, R. Dave and L. Meyer (eds.), Climate Change 2007: Mitigation. 
Contribution of Working Group III to the Fourth Assessment Report of the Inter-governemental Panel on Climate Change, Cambridge University Press, Cambridge.

Hahn, R. and R. Stavins (1991), "Incentive-Based Environmental Regulation: A New Era from an Old Idea?”, Ecology Law Quarterly, Vol. 18, No. 1.

Hanks, J. (2002), "Voluntary Agreements, Climate Change and Industrial Energy Efficiency", Journal of Cleaner Production, Vol. 10, No. 2.

Hassett, K. and G. Metcalf (1995), "Energy Tax Credits and Residential Conservation Investment: Evidence from Panel Data", Journal of Public Economics, Vol. 57, No. 2.

Helm, D. (2005), Climate Change Policy, Oxford University Press, Oxford.

Helm, D., C. Hepburn and R. Mash (2004), "Time-inconsistent Environmental Policy and Optimal Delegation”, Oxford University Department of Economics Discussion Paper No. 175.

Hoel, M. and L. Karp (2001), "Taxes and Quotas for a Stock Pollutant with Multiplicative Uncertainty", Journal of Public Economics, Vol. 82, No. 1.

IEA (2007), Mind the Gap, Paris.

Jaffe, A., R. Newell and R. Stavins (2003), "Technological Change and the Environment", in K-G. Mäler and J. Vincent (eds.), Handbook of Environmental Economics, Vol. 1, North Holland, Amsterdam.

Jaffe, A. and R. Stavins (1995), "Dynamic Incentives of Environmental Regulations: The Effects of Alternative Policy Instruments on Technology Diffusion", Journal of Environmental Economics and Management, Vol. 29, No. 3.

Jaumotte, F. and N. Pain (2005), "Innovation in the Business Sector", OECD Economics Department Working Paper No. 459.

Johnston, A. (2006), "Free Allocation of Allowances under the EU Emissions Trading Scheme: Legal Issues", Climate Policy, Vol. 6, No. 1.

Jotzo, F. and J. Pezzey (2007), "Optimal Intensity Targets for Greenhouse Gas Emissions Trading Under Uncertainty”, Environmental and Resource Economics, Vol. 38, No. 2.

Jung, C., K. Krutilla and R. Boyd (1996), "Incentives for Advanced Pollution Abatement Technology at the Industry Level: An Evaluation of Policy Alternatives", Journal of Environmental Economics and Management, Vol. 30, No. 1.

Kennedy, P. and B. Laplante (1999), "Environmental Policy and Time Inconsistency: Emissions Taxes and Emissions Trading", in E. Petrakis, E. Sarzetakis and A. Xepapadeas (eds.), Environmental Regulation and Market Power: Competition, Time Inconsistency and International Trade, Northampton, Edward Elgar, UK.

Keohane, N. (1999), "Policy Instruments and the Diffusion of Pollution Abatement Technology", mimeo, Harvard University.

Keohane, N. (2001), Essays in the Economics of Environmental Policy, Ph.D. Dissertation, Harvard University. 
Kerr, S. and D. Maré (1998), "Transaction Costs and Tradable Permit Markets: The United States Lead Phasedown", mimeo, Motu Economic and Public Policy Research.

Kerr, S. and R. Newell (2004), "Policy-Induced Technology Adoption: Evidence from the U.S. Lead Phasedown”, Journal of Industrial Economics, Vol. 51 No. 3.

Kolstad, C. (2006), "The Simple Analytics of Greenhouse Gas Emission Intensity Reduction Targets", Energy Policy, Vol. 33, No. 17.

Kremer, M. (2001a), "Creating Markets for New Vaccines: Part I: Rationale”, in B. Jaffe, J. Lerner and S. Stern (eds.), Innovation Policy and the Economy, Vol. 1, MIT Press, Cambridge, Massachussets.

Kremer, M. (2001b), "Creating Markets for New Vaccines: Part II: Design Issues", in B. Jaffe, J. Lerner and S.Stern (eds.), Innovation Policy and the Economy, Vol. 1, MIT Press, Cambridge, Massachussets.

Krysiak, F. (2008), "Prices vs. Quantities: The Effects on Technology Choice", Journal of Public Economics, Vol. 92, No. 5.

Levine, M., D. Hirst, E. Koomey, J. McMahon and A. Sanstad (1994), Energy Efficiency, Market Failures and Government Policy, Lawrence Berkeley Laboratory and Oak Ridge Laboratory, Berkeley, CA.

Maeda, A. (2003), "The Emergence of Market Power in the Emission Rights Markets: The Role of Initial Permit Distribution", Journal of Regulatory Economics, Vol. 24, No. 3.

Marcu, M. and W. Pizer (eds.) (2003), "Special Supplement on Defining and Trading Emission Targets", Climate Policy, Vol. 3, Supplement 2.

Marsiliani, L. and T. Renström (2000), "Time Inconsistency in Environmental Policy: Tax Earmarking as a Commitment Solution”, The Economic Journal, Vol. 110, No. 462.

McKibbin, W. and P. Wilcoxen (2002), Climate Change Policy After Kyoto: A Blueprint for a Realistic Approach, Brookings Institution, Washington D.C.

McKibbin, W. and P. Wilcoxen (2007), “A Credible Foundation for Long Term International Cooperation on Climate Change", in J. Aldy and R. Stavins (eds.), Architectures for Agreement: Addressing Global Climate Change in the Post-Kyoto World, Cambridge University Press, Cambridge.

Milliman, S. and R. Prince (1989), "Firm Incentives to Promote Technological Change in Pollution Control", Journal of Environmental Economics and Management, Vol. 17, No. 3.

Montero, J-P. (2002), "Permits, Standards, and Technology Innovation", Journal of Environmental Economics and Management, Vol. 44, No. 1.

Montero, J-P. (2005), "Pollution Markets with Imperfectly Observed Emissions", RAND Journal of Economics, Vol. 36, No. 3.

Müller, B. and G. Müller-Fürstenberger (2003), "Price-Related Sensitivities of Greenhouse Gas Intensity Targets", Climate Policy, Vol. 3, Supplement 2.

Newell, R. and W. Pizer (2003), "Regulating Stock Externalities under Uncertainty", Journal of Environmental Economics and Management, Vol. 45, No. 2. 
OECD (1999), Action Against Climate Change: The Kyoto Protocol and Beyond, Paris.

OECD (2003), Voluntary Approaches for Environmental Policy: Effectiveness, Efficiency and Usage in Policy Mixes, Paris.

OECD (2006), The Political Economy of Environmentally Related Taxes, Paris.

OECD (2007a), "Environmentally Related Taxes and Tradable Permits in Practice", COM/ENV/EPOC/CTPA/CFA(2007)31.

OECD (2007b), “Instrument Mixes for Environmental Policy”, ENV/EPOC/WPNEP(2006)9/REV2.

Olson, M. (1965), The Logic of Collective Action, Harvard University Press, Cambridge, Massachusetts.

Palmer, K., W. Oates and P. Portney (1995), "Tightening Environmental Standards: The Benefit-Cost or the No-Cost Paradigm?” Journal of Economic Perspectives, Vol. 9, No. 4.

Parry, I. (1998), "Pollution Regulation and the Efficiency Gains from Technological Innovation", Journal of Regulatory Economics, Vol. 14, No. 3.

Parry, I., W. Pizer and C. Fischer (2003), "How Large are the Welfare Gains from Technological Innovation Induced by Environmental Policies?”, Journal of Regulatory Economics, Vol. 23, No. 3.

Perez, R. (2007), “Towards a Generalized System of Environmental Tariffs?”, mimeo, United Nations.

Pezzy, J. and A. Park (1998), "Reflections on the Double Dividend Debate: The Importance of Interest Groups and Information Costs", Environmental and Resource Economics, Vol. 11, Nos 3-4.

Pigou, A. (1920), The Economics of Welfare, Macmillan and Company, London.

Pizer, W. (2002), "Combining Combining Price and Quantity Controls to Mitigate Global Climate change", Journal of Public Economics, Vol. 85, No. 3.

Pizer, W. (2005), “The Case for Intensity targets”, Climate Policy, Vol. 5, No. 4.

Porter, M. and C. van der Linde (1995), "Toward a New Conception of the Environment-competitiveness Relationship", Journal of Economic Perspectives, Vol. 9, No. 4.

Quirion, P. (2005), "Does Uncertainty Justify Intensity Emission Caps?", Resource and Energy Economics, Vol. 27, No. 4.

Roberts, M. and M. Spence (1976), "Effluent Charges and Licenses Under Uncertainty", Journal of Public Economics, Vol. 5, No. 3-4.

Russell, C. and W. Vaughan (2003), "The Choice of Pollution Control Policy Instruments in Developing Countries: Arguments, Evidence and Suggestions", in H. Folmer and T. Tietenberg (eds.), The International Yearbook of Environmental and Resource Economics, 2003/2004, Cheltenham, Edward Elgar, U.K.

Schelling, T. (2007), "Climate Change: the Uncertainties, the Certainties, and What They Imply About Action", The Economists' Voice, Vol. 4, No. 3. 
Schneider, S. and L. Goulder (1997), “Achieving Low-cost Emissions Targets”, Nature, Vol. 389, No. 4.

Schmalensee, R. (1994), "The Costs of Environmental Protection", in M. Kotowski (ed.), Balancing Economic Growth and Environmental Goals, American Council for Capital Formation, Center for Policy Research, Washington D.C.

Sinn, H-W. (2007), "Public Policies Against Global Warming”, CESifo Working Paper No. 2087.

Sorrell, S. (2002), The Climate Confusion: Implications of the EU Emissions Trading Scheme for the UK Climate Change Levy and Climate Change Agreements, Science and Technology Policy Research (SPRU), University of Sussex, Brighton.

Sorrell, S., J. Schleich, S. Scott, E O'Malley, F. Trace, U. Boede, K. Ostertage and P. Radgen (2000), Barriers to Energy Efficiency in Public and Private Organisations, Science and Technology Policy Research, University of Sussex, Brighton.

Sorrell, S. and J. Sijm (2003), "Carbon Trading in the Policy Mix", Oxford Review of Economic Policy, Vol. 19, No. 3 .

Stavins, R. (1997), "Policy Instruments for Climate Change: How Can National Governments Address a Global Problem?", The University of Chicago Legal Forum, Vol. 1997.

Stavins, R. (1996), "Correlated Uncertainty and Policy Instrument Choice", Journal of Environmental Economics and Management, Vol. 30, No. 2.

Stavings, R. (2003), "Experience with Market-based Environmental Policy Instruments", in K-G. Mäler and J. Vincent (eds.), Handbook of Environmental Economics, Vol. 1, North Holland, Amsterdam.

Stern, N. (2007), The Economics of Climate Change: The Stern Review, CUP, Cambridge.

Sterner, T. (2003), Policy Instruments for Environmental and Natural Resource Management, Resources for the Future Press, Washington D.C.

Stiglitz, J. (2006), “A New Agenda for Global Warming”, The Economists’ Voice, Vol. 3, No. 7.

Walter, A., F. Rosillo-Calle, P. Dolzan, E. Piacente and K. Borges da Cunha (2007), "Market Evaluation: Fuel Ethanol", Task 40 Sustainable Bio-energy Trade: Securing Supply and Demand (Deliverable 8), State University of Campinas (Unicamp), Campinas, Brazil.

Weitzman, M. (1974), “Prices vs. Quantities”, Review of Economic Studies, Vol. 41, No. 4.

Weitzman, M. (2007), "Structural Uncertainty and the Value of Statistical Life in the Economics of Catastrophic Climate Change", NBER Working Paper No. 13490.

Zerbe, R. (1970), “Theoretical efficiency in Pollution Control”, Western Economic Journal, Vol. 8, No. 4. 
$\mathrm{ECO} / \mathrm{WKP}(2008) 44$

\section{WORKING PAPERS}

The full series of Economics Department Working Papers can be consulted at www.oecd.org/eco/Working_Papers/

635 Quantifying the effect of financial conditions on US activity (September 2008) Stéphanie Guichard and David Turner

634. Have long-term financial trends changed the transmission of monetary policy (September 2008), Stéphanie Guichard and David Turner

633. Raising education achievement and breaking the cycle of inequality in the United Kingdom (August 2008) Anne-Marie Brook

632. The euro changeover in the Slovak Republic: implications for inflation and interest rates (August 2008) Felix Hüfner and Isabell Koske

631. Tax reform for efficiency and fairness in Canada (August 2008) Alexandra Bibbee

630. Reforming the Polish Tax System to Improve its Efficiency (August 2008) Alain de Serres

629. Modernising Canada's Agriculture Policies (August 2008) Peter Jarrett and Shuji Kobayakawa

628. Recent trends and structural breaks in US and EU15 labour productivity growth (August 2008) Laure Turner and Hervé Boulhol

627 Health Status Determinants: Lifestyle, Enviroment, Health Care Resources and Efficiency (August 2008) Isabelle Joumard, Christophe André, Chantal Nicq and Olivier Chatal

626. Market Mechanisms in Public Service Provision (August 2008) Hansjörg Blöchliger

625. Improving human capital formation in India (July 2008) Sean S. Dougherty and Richard Herd

624. Labour regulation and employment dynamics at the state level in India (July 2008) Sean S. Dougherty

623. India's growth pattern and obstacles to higher growth (July 2008) Sean S. Dougherthy, Richard. Herd, Thomas. Chalaux and Abdul. Erumban

622. Reaping the benefits of stronger competition in network industries in Germany (July 2008) Nicola Brandt

621. The Usefulness of Output Gaps for Policy Analysis (July 2008) Isabell Koske and Nigel Pain 
620. Taxation and Economic Growth

(July 2008) Asa Johansson, Christopher Heady, Jens Arnold, Bert Brys and Laura Vartia

619. Coping with labour shortages: How to bring outsiders back to the labour market (July 2008) Ekkehard Ernst

618. Achieving sustainability of the energy sector in Canada (June 2008) Annabelle Mourougane

617. The Dutch tax-benefit system and life-cycle employment. Outcomes and reform options (June 2008) Ekkehard Ernst and Timo Teuber

616. Regulation, Allocative Efficiency and Productivity in OECD Countries: Industry and Firm-Level Evidence

(May 2008) Jens Arnold, Giuseppe. Nicoletti, and Stefano Scarpetta

615. Public social spending in Korea in the context of rapid population ageing (May 2008) Randall S. Jones

614. Enhancing the globalisation of Korea

(May 2008) Randall S. Jones and Taesik Yoon

613. Reforming housing and regional policies in Korea

(May 2008) Randall S. Jones and Tadashi Yokoyama

612. Moving towards more sustainable healthcare financing in Germany (May 2008) N. Brandt

611. Improving education outcomes in Germany (May 2008) David Carey

610. Have developed countries escaped the curse of distance? (May 2008) Hervé Boulhol and Alain de Serres

609. Measures of international transport cost for OECD countries (April 2008) Stephen S. Golub and Brian Tomasik

608. Encouraging labour force participation in Chile (April 2008) D. Contreras, L. de Mello and E. Puentes

607. Tackling business and labour informality in Chile (April 2008) D. Contreras, L. de Mello and E. Puentes

606. Delivery cost-efficient public services in health care, education and housing in Chile (April 2008) D. Contreras, L. de Mello and E. Puentes

605. Managing Chile's macroeconomy during and after the copper price boom (April 2008) Luiz de Mello 